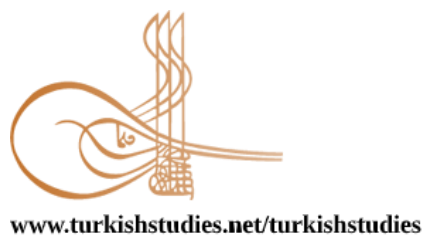

Turkish Studies

www.turkishstudies.net/turkishstudies

TERNATIONAL

BALKAN

Sponsored by IBU

Research Article / Araștırma Makalesi

\title{
Ortaçağ Anadolu Türk İslam Mimarisinde Kanat ve Kuyrukları Ejderle Biten Figürler
}

\author{
Figures With Dragon Tails and Wings in Medieval Anatolian Turkish-Islamic Architecture
}

\author{
Fatmagül Saklavci*
}

\begin{abstract}
The dragon is one of the winged mythological and legendary figures with the head of a crocodile, lion, wolf or dog, its body in the form of a snake or fish. The figures, depicted in Islamic art, became widespread after the Turks came to Asia Minor and Iran, and were used extensively in the works of the Anatolian Seljuk period. In the period between H. 605 / M. 1208 and H. 777 / M. 1375 in medieval Anatolian Turkish architecture, dragon figures were depicted on the tails of lions, on the wings of double-headed eagle and sirens as mythological figures. In this study, based on these applications in architectural structures, the symbolic meanings of the figure in different periods and cultures were investigated, and evaluations and comparisons were made about its use in stone, metal and woodworking, miniature and tile arts. During the period, 20 figures were identified in 8 structures, including 2 castles, 2 caravanserais, 1 mosque, 1 zawiya and 2 cupolas. The double-headed eagle with dragon wings are located in Niğde Hüdavend Hatun Tomb and Divriği Ulu Mosque. Dragon tailed lions are located in Hasankeyf Castle Small Palace, Ulu Body Bastion, Kesikköprü Han, Hüdavend Hatun Vault, Dazya Village Lodge and Erçiş Zortul Vault. 2 of the structures are Artuqid, 2 Anatolian Seljuk, 1 Mengücek, 1 İlhanlı, 1 Eretna, 1 Karakoyunlu period. The figures, were located on the exterior of the buildings are generally depicted in the Seljuk style. In the castle, inn and mosque, it is thought that lion and double-headed eagles which are symbols of sun, usually represent the sultan and power, dragons which are symbols of moon, underground, dark, represent the enemy. They represent two opposite principles on the same figure and are depicted much stronger together. In the tombs the dragon figures, which are depicted together with the eagle and siren figures, are used as amulets to protect the person lying in the tree of life designs. The research has shown that the dragon figures, which shed light on the cultural levels and social lives of the communities they belong to, have not lost their meaning in the historical process and have preserved their functional characteristics, even though they are included in different works of art in different eras and cultures.
\end{abstract}

Structured Abstract: One of the figures that are symbolic expressions of people's feelings and thoughts in works of art is the dragon. Figures are winged mythological and mythical creature with a head in the form of a crocodile, lion, wolf or dog, body in the form of a snake or fish. They, started to be seen in Central Asia before Christ and was used extensively in the Middle Ages Anatolian Seljuk period, has various meanings in many periods and cultures. Dragon figures are seen alone and mutually in some works. In some medieval Anatolian structures, they were depicted on the tails of lion figures, on the wings of figures such as double-headed eagles and sirens. One of the reasons for doing this study is to examine the figures in these structures, to investigate the use of dragon figures in this way and to compare the functional features of the figure on different works, in different cultures and practices. Although there have been many studies on dragon figures used as ornaments

\footnotetext{
* Dr. T.C. Kültür ve Turizm Bakanlığı Geleneksel Hüsn-i Hat ve Tezhip Sanatkâr1 Dr. Ministry of Culture and Tourism Traditional Calligraphy and Illumination Artist ORCID 0000-0001-9274-5111

saklavci@gmail.com

Cite as/ Atıf: Saklavc1, F. (2021). Ortaçağ Anadolu Türk İslam mimarisinde kanat ve kuyrukları ejderle biten figürler . Turkish Studies, 16(5), 1593-1617. https://dx.doi.org/10.7827/TurkishStudies.52312

Received/Geliş: 11 August/Ağustos 2021

Accepted/Kabul: 25 October/Ekim 2021 Checked by plagiarism software CC BY-NC 4.0
}

Published/Yayın: 30 October/Ekim 2021 
until today, it is seen that information about dragon figures on the tail and wings is rare. Our aim is to examine the studies on these dragon figures and their uses to provide information by researching their use in architecture. For this purpose, using the qualitative research method in our study, the literature was searched, the documents were examined and reliable sources were reached. Based on the applications of the figures in the architectural works, the documents related to the use of stone, metal and woodworking, miniature and tile arts were examined and comparisons were made. We determined 20 figures with dragon figures depicted on their tails and wings in 8 structures, including 2 castles, 2 caravanserais, 1 mosque, 1 zawiya and 2 cupolas. The evaluations in our study were made on the basis of the examination of the figures in these structures, with the figures on which the dragon figures were applied were grouped and we introduced these figures Dragon figures designed at the end of the wings of the double-headed eagle figure are located in Niğde Hüdavend Hatun Tomb and Divriği Ulu Mosque. Dragon figures on the tail of the lion figures are located in Hasankeyf Castle Small Palace, Ulu Body Bastion, Kesikköprü Han, Hüdavend Hatun Vault, Dazya Village Lodge and Erçiş Zortul Vault. 2 of the structures belong to the Artuqid, 2 to the Anatolian Seljuk, 1 to Mengücek, 1 to İlhanl, 1 to Eretna, 1 to Karakoyunlu period. The dragon figure is important in Asian cosmology and mythology. The figure, which is of Central Asian origin in Turkish art from China, goes back to the Sumerians and represents the kingdom in Ancient Egypt. They become widespread in Islamic art after the Turks came to Asia Minor and Iran. The figure, which is an astrological element symbolizing water resources and rain clouds, is a symbol of goodness, evil, health and bravery in ancient Turks and in the Central Asian beliefs. They represent the symbol of harmony, universe, sky, movement, struggle with evil, underground, darkness and planet in the structures, the year of the dragon in the Turkish Calendar with 12 Animals. On the stone belonging to the Konya Castle and on the wooden medallion from the Tuketa Kurgan, there is a design with the sky wheel turned by two dragons. The dragon figure in miniatures is depicted as snake and dragon in legends. In some of the Bektashi legends in Anatolian beliefs, figure is a feared symbol shaped by the ancient religions and mythological elements of the Turks, is the symbol of the respect for the saint, his spiritual power, training of his soul. It is also used in various cult items such as the mirror, the nefir, the universe, and the keşkul with Sufi belief. The dragon head in the tail, which is the subject of our study, is one of the characteristics of the Seljuk style dragon figures and it has become widespread after the Turks came to Asia Minor and Iran. There is a fish-bodied, leopard or lion-headed dragon in the Çikan Köl wall painting, which is thought to belong to the 8th century, one of the early Uyghur works in Turkestan. On the pieces brought from Seljuk structures in Konya İnce Minare Stone and Wooden Works Museum, there are scenes of struggle with a second dragon on its tail. It is possible to say that these depictions show the effects of the Oghuz and Uyghur periods. The figures are located on the exterior of the buildings and are generally depicted in the Seljuk style. When we evaluate the use of dragon figures in buildings, it is possible to say that in castles, inns and mosques, the lion and double-headed card figures usually symbolize the sultan, the power indicator representing the state, and the dragon figures, which are depicted as ready to attack on their tails, symbolize the enemy. While the lion figures are the symbols of power and victory in the buildings, it suggests that the winged lion figures are applied together to combine two opposite principles on the same figure, which expresses extraordinary strength. It can be said that figures with dragon wings, represent the light and the sun as symbols are given together in a much stronger way. When the compositions in the tombs are evaluated, it is seen that the lion, double-headed eagle and dragon figures, which are the elements of the tree of life, are used on the same facade in the tombs. Thus, although the implementation of the figures is different, it is seen that they are used as talismans and amulets that protect the person lying in the building. As a result, our study has shown that the figures that started to be used in Central Asia BC, although the Turks came to Anatolia from Central Asia and met with new beliefs and cultures, they did not lose their meaning in the historical process and carry the traces of old beliefs. It is seen that the figures have almost the same symbolic meanings in the wooden and metal finds unearthed from the kurgans, in the book paintings, miniatures, stone and metal works exhibited in the museums, examples of Anadolu Turkish architecture, 19th century religious artifacts. Although the dragon depicted alone or together with different figures are applied in different works of art in different periods and cultures, they reflect the cultural levels and social lives of the communities they belong to. Thus, it is seen that the historical elements that the figures convey by reflecting the meanings and history play a functional and impressive role in human life.

Keywords: Art History, Medieval, Anatolia, Turkish Architecture, dragon, wing, tail

Öz: Ejder, başı timsah, arslan, kurt ya da köpek görünümünde, gövdesi yılan veya balık şeklinde, kanatlı mitolojik ve efsanevi figürlerden birisidir. İslam sanatında tasvir edilen figürler arasında yer alan ejderler, 
Türklerin İran ve Ön Asya’ya gelmesi ile birlikte yayılmış, Anadolu Selçuklu dönemi eserlerinde yoğun olarak betimlenmiştir. Ortaçağ Anadolu Türk mimarisinde H. 605 /M.1208 tarihi ve H.777 / M. 1375 tarihi arasındaki süreçte yapıların bazılarında ejder figürü arslan figürlerinin kuyruklarında, bazılarında çift başlı kartal ve siren figürlerinin kanatlarında tasvir edilerek mitolojik birer figür halini almıştır. Bu çalışmada mimari yapılardaki bu uygulamalardan yola çıkılarak figürün farklı devir ve kültürlerde taşıdığı sembolik anlamlar araştırılmış, taş, metal ve ahşap işçiliği, minyatür ve çini sanatlarında kullanımı ile ilgili değerlendirme ve karşılaştırmalar yapılmıştır. Araştırma yapılan dönem içerisinde 2 kale, 2 kervansaray, 1 cami, 1 zaviye ve 2 kümbet olmak üzere 8 yapıda 20 figür tespit edilmiştir. Çift başlı kartal figürünün kanatlarının bitiminde tasarlanan ejder figürleri, Niğde Hüdavend Hatun Türbesi ve Divriği Ulu Camii'nde bulunmaktadır. Arslan figürlerinin kuyruğunda yer alan ejder figürleri Hasankeyf Kalesi Küçük Saray, Ulu Beden Burcu, Kesikköprü Han, Hüdavend Hatun Kümbeti, Dazya (Gümüş Top) Köyü Zaviyesi ve Erçiş Zortul Kümbeti'nde bulunmaktadır. Yapıların 2'si Artuklu, 2'si Anadolu Selçuklu, 1'i Mengücek, 1'i İlhanlı, 1'i Eretna, 1'i Karakoyunlu dönemine aittir. Figürler yapıların dış cephelerinde yer almaktadır ve genel olarak Selçuklu stilinde tasvir edilmiştir. Kale, han ve camide genellikle arslan ve çift başlı kartal figürlerinin sultanı, devleti temsil eden güç göstergesi; kuyruklarında saldırmaya hazır olarak verilen ejder figürlerinin ise düşmanı simgelediği, böylece aynı figür üzerinde iki zıt prensibi temsil etmek üzere birlikte tasarlandığı düşünülmektedir. Böylelikle aydınlık ve güneş simgesi olan figürler çok daha güçlü olacak şekilde birlikte betimlenmiştir. Çift başlı kartal ve arslan figürleri; güneş, aydınlık, ejder figürü ise; ay, yer altı, karanlık sembolüdür. Türbelerde ise kartal ve siren figürleri ile birlikte tasvir edilen ejder figürlerinin hayat ağacı tasarımlarında yapıda yatan kişiyi koruyan tılsım ve muska olarak kullanıldığı görülmektedir. Ait oldukları toplulukların kültür düzeylerini ve sosyal yaşamlarına ışık tutan ejder figürleri, farklı devir ve kültürlerde, farklı sanat eserlerinde yer alsalar da tarihi süreç içerisinde anlamlarını yitirmemiş, işlevsel özelliklerini korumaya devam etmişlerdir.

Anahtar Kelimeler: Sanat Tarihi, Ortaçağ, Anadolu, Türk Mimarisi, ejder, kanat, kuyruk

\section{Giriş}

Sanat eserlerinde insanların duygu ve düşüncelerinin sembolik ifadeleri olan mitolojik ve efsanevi figürlerden birisi de ejderdir. Milattan önce Orta Asya'da uygulanmaya başlanan, Orta Çă̆ Anadolu Selçuklu dönemi eserlerinde de yaygın olarak tasvir edilen figür, birçok devir ve kültürde çeşitli anlamlar ifade etmektedir. Ejder figürleri eserlerde; başları timsah, arslan, kurt ya da köpek, gövdesi yılan veya balık şeklinde, kanatlı, pullu, keskin dişli olarak tasvir edilmiştir. İslâm kültüründe önemli yeri olan ejder figür mimari, çini, maden, minyatür sanatlarında, taş işçiliğinde; şifahane, kale, han, saray gibi mimari yapılarda süsleme ögesi olarak kullanılmıştır.

Ejder figürleri eserlerde tek başına ve karşıllklı tasvir edildiği gibi arslan figürlerin kuyruklarında, çift başlı kartal ve siren gibi figürlerin kanatlarında da tasvir edilmiştir. Bazı eserlerde ise ejderler kendi gövdelerindeki ikinci bir ejder başı ile mücadele halindedir. Orta Çağ Anadolu Türk mimarisi taş işçiliğinde de bu bu tür örneklere rastlanmaktadır. Bu çalışmayı yapmamızdaki sebeplerden birisi araştırmalarımız sonucu tespit ettiğimiz kuyruk ve kanatlarında ejder tasvirleri bulunan yapıları ve figürleri yerinde incelemek, figürlerin bu şekilde kullanımlarını araştırmak ve figürün farklı eserler üzerinde, farklı devir ve uygulamalardaki işlevsel özelliklerinin karşılaştırmasını yapmaktır. Günümüze kadar süsleme ögesi olarak kullanılan ejder figürleri ile ilgili birçok araştırma yapılmış olmasına rağmen kuyruk ve kanatlarda yer alan ejder figürleri ile ilgili bilgilerin nadir olduğu görülmektedir. Amacımız bu uygulamalar ile ilgili araştırma yaparak konuya katkıda bulunmaktır. Bu amaç doğrultusunda çalışmamızda nitel araştırma yöntemi kullanılarak, araştırmaya yardımcı olacak güvenilir kaynak ve dokümanların taraması yapılmıştır. Figürlerin mimari eserlerdeki uygulamalarından yola çıkılarak müzelerde sergilenen eserler, taş, metal ve ahşap işçiliği, minyatür ve çini sanatlarında kullanımı ile ilgili dokümanlar incelenmiş, karşılaştırma ve değerlendirme yapılmıştır. 
Orta Çağ dönemi Türk İslam yapıları araştırıldığında ejder figürlerinin görüldüğü tarihi en eski yapının 12. yüzyıl Artuklu döneminde inşa edilen Cizre Köprüsü (Çulpan, 1975: 44; Özkan, 1993: 40), en geç tarihli yapının ise H. 825 / M. 1420'de inşa edilen Karaman Araboğlu Cami'si olduğu belirlenmiştir (Aslanapa\&Diez, 1955: 35; Özüdoğru, 1989: 29; Görür, 1999: 26). Çalışmamıza konu olan kanat ve kuyruklarında ejder figürü yer alan en erken tarihli yapı ise Artuklu dönemine ait, H. 605 /M.1208 tarihli Diyarbakır Kalesi Ulu Beden Burcu (Aslanapa, 1971: 17; Gabriel, 1993: 23); en geç örnek ise H.777 / M. 1375 tarihli Dazya Köyü Zaviyesi'dir (Yurdakul, 1969: 245; Gündoğdu, 2004: 74). Araştırma yaptığımız 8 yapıda kuyruk ve kanatlarında ejder figürü olan 20 figür tespit edilmiştir. Bu yapılar: 2 kale, 2 kervansaray, 2 kümbet, 1 cami ve 1 zaviyedir. Çalışmamızdaki değerlendirmeler bu yapılardaki figürlerin incelenmesinden yola çıkılarak yapılmış, ejder figürlerinin uygulandığı figürlerin bulunduğu yapılar gruplandırılmış, yapılar ve figürler hakkında bilgi verilmiştir. Çalışma yaptığımız dönem içerisinde daha erken tarihli yapı olan, Artuklu dönemi 1206 tarihli Sitti Radviye (Hatuniye) Hamamı'nın soyunmalık kısmında yer alan figürler tahrip oldukları için tam olarak seçilememektedir. Girişin sol üst yanında, yürür vaziyette mücadele halinde olduğu düşünülen figürler yer almaktadır. Bu figürlerden alt tarafta profilden verilmiş, başı yukarı doğru kalkmış gövdesi plastik bir biçimde işlenen aslan figürün kuyruğunun yukarı doğru "C" şeklinde kıvrık olduğu ve ucunun ejder başı veya bitkisel bir motif şeklinde sonlandığı düşünülse de tam bir kesinlik arzetmediği için (Çetin, 2013: 180) bu çalışmaya dâhil edilmemiştir.

\section{1. Çift Başlı Kartal Figürünün Kanatlarının Bitiminde Tasarlanan Ejder Figürleri}

Çift başlı kartal figürünün kanatlarının bitiminde verilmiş ejder figürleri, Divriği Ulu Cami ve Niğde Hüdavend Hatun Türbesi’nde bulunmaktadır. Yapılarda kartal figürlerinin gövdeleri stil olarak farkl11ıklar gösterirken ejder figürleri benzer şekilde tasvir edilmiştir.

1a. Divriği Ulu Cami'nin (H. 626/M. 1228-1229) (Gabriel, 1934: 175; Ülgen, 1962: 93-94; Arel, 1962: 113-127; Sözen, 1972: 8; Bakırer, 2000: 152; Aslanapa, 2007: 25-26; Kuban, 2010: 40; Durukan, 2012: 20; Çobanoğlu, 2012: 95; Cantay, 2014: 51) batı taçkapısında, kuzey ve güney kavsara nişlerindeki panolarda çift başı kartal figürlerinin kanatları profilden verilmiş ejder başları ile sonlanmaktadır (Öney, 1971: 209). Gövdesi cepheden, başları yandan verilen kartal figürleri detaylı olarak tasvir edilmiştir. Figürlerin gövde ve kanatları dairesel, damla ve çizgisel formlarla kabarık ve çukur olarak işlenmiştir. Kuyruklarının altında yelpaze şeklinde bir kuyruk daha bulunmaktadır. Kuyruklar gövdeye yuvarlak bir agraf motifi ile bağlanmış, iki yana açılmıştır. Ejderlerin ağızlarının üst kısmı dışa doğru kıvrık, kulakları sivri ve gözleri badem şeklindedir. Figürler yuvarlak gözlü, içe dönük sivri gagalı, ibikli olarak işlenmiştir. Yüz detaylarının tasvirlerinde çukur, kabarık ve çizgi formlardan faydalanılmış, boyunlarından başlarının arka taraflarına doğru sıralı küçük çukur formlarla süslenmiştir. Kanatlarının uçlarında ejder motifler görülmekte, alt taraflarından rumi bir agraf ile birleşmektedir. Kanatlardaki tüyler detaylı olarak verilmiş̧ir. Ejder figürünün açık olan ağzı ve gözleri çukur çizgilerle oluşturulmuştur (Foto. 1-2, Çiz. $1-2)$. 


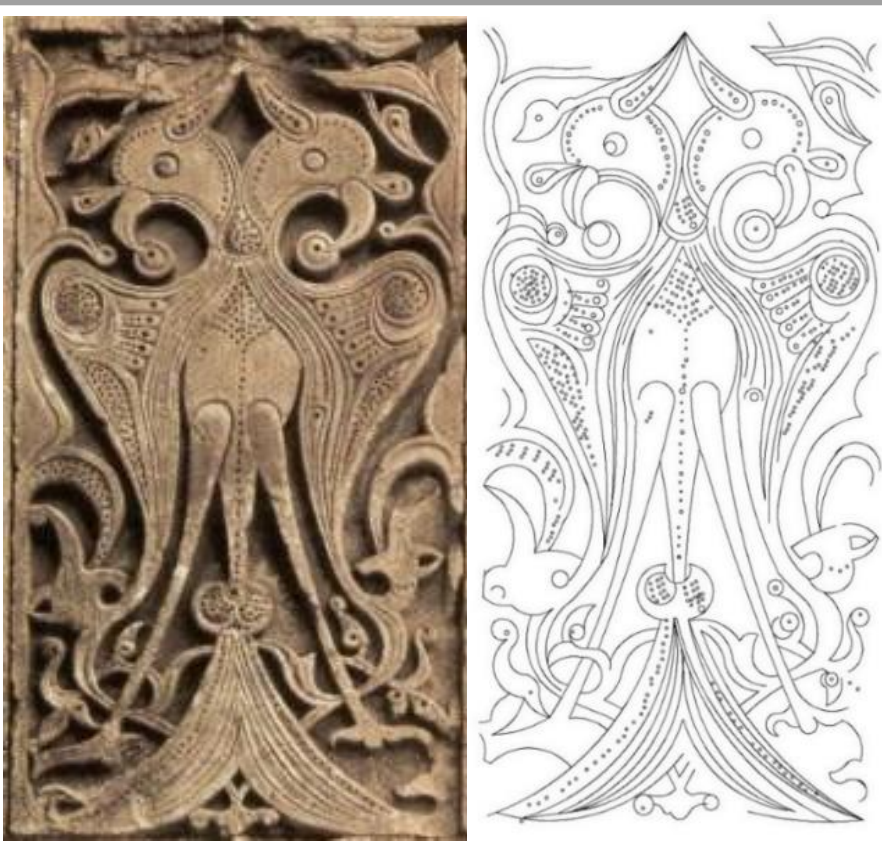

Fotoğraf 1. Çizim 1. Batı Taçkapı, Kuzey Duvar, Figürler ve Çizimi.
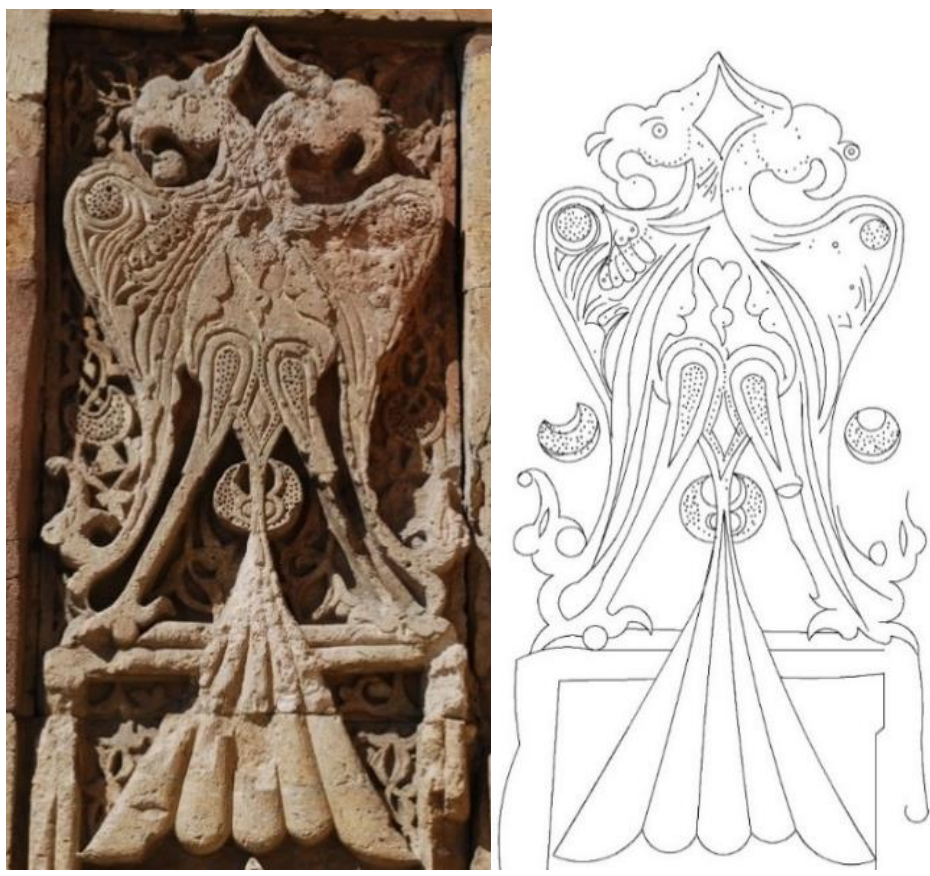

Fotoğraf 2. Çizim 2. Batı Taçkap1, Güney Duvar, Figürler ve Çizimi

1b. Hüdavend Hatun Kümbeti'nin (H. 712-713/M. 1312-13) (Akalın, 1998: 284-285; Gabriel, 1999: 119; Önkal, 2015: 159; Özkarc1, 2017: 152) batı taraf nişi içerisindeki çift başlı kartal figürü uzun bacaklı, şişkin gövdeli, yelpaze şeklinde kısa kuyrukludur. Figürün bacak eklemleri detaylı, gövdesi, kuyruğu ve kanatları kabartma şeklinde tasvir edilmiştir. Tüy detayları belirgin değildir. Başı tahrip olmuş figürün kanatlarının uçlarında profilden verilmiş ejder figürlerinin açık ağızları volut şeklinde dışa kıvrıktır (Foto. 3, Çiz. 3). 


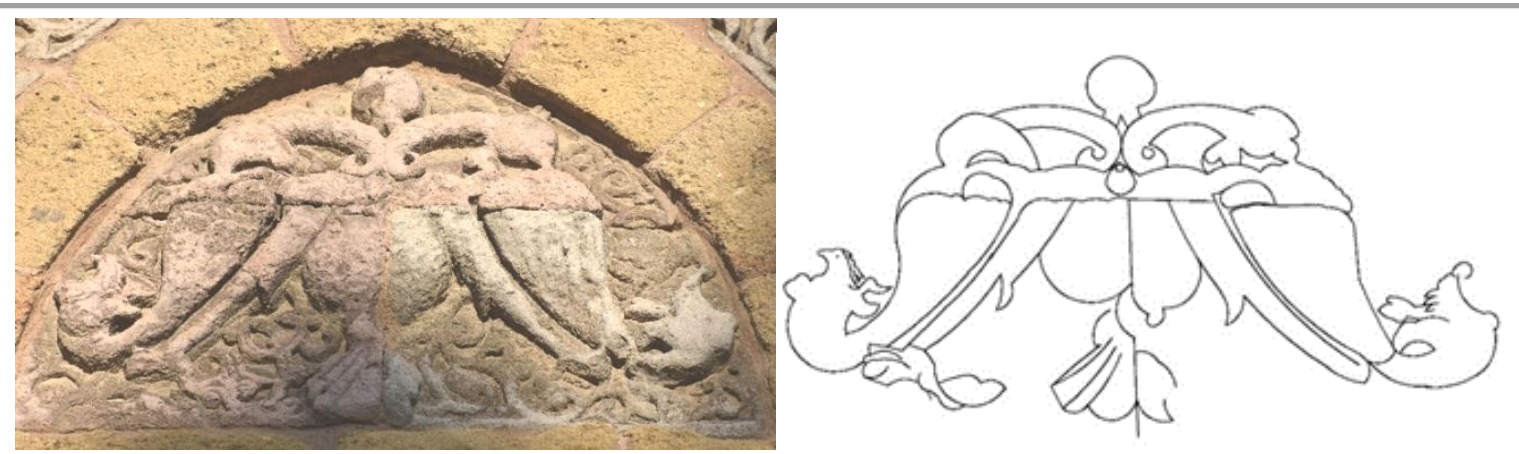

Fotoğraf 3, Çizim 3. Çift Başlı Kartal ve Ejder Figürleri, Çizimi.

\section{Siren Figürlerinin Kanatlarında Yer Alan Ejder Figürleri}

Niğde Hüdavend Hatun Kümbeti’nin (H. 712-713/M. 1312-13) (Akalın, 1998: 284-285; Gabriel, 1999: 119; Önkal, 2015: 159; Özkarc1, 2017: 152) taçkapısının güneydoğu cephesinde, pencere kemerinin iki üst köşelerinde iki siren figürü bulunmaktadır. Sirenlerin aralarında ikisi küçük, ortadaki büyük, dışa taşkın üç rozet yer almaktadır. Gövdeleri profilden, başları cepheden verilen figürler simetrik ve karşılıklı yüksek kabartma şeklinde yerleştirilmiştir. Figürlerin gövdeleri pul şeklinde çizgilerle tüyle kaplı olarak tasvir edilmiştir. Uzun çizgilerden faydalanılarak işlenen kanatlarında çarkıfelek desenli rozet vardır. Kuyrukları dilimli ve yelpaze şeklinde çizgisel formlarla şekillendirilmiştir. Figürlerin sırtlarındaki yükselen ve ejder başı ile biten ikinci bir kanat seçilmektedir. Bu ejder figürleri Selçuklu stilinde başı dışa dönük, ağzı açık, dili dışarda ve badem gözlüdür. Siren figürleri de Selçuklu yüz tipine uygun yuvarlak yüzlüdür. Detaylı işlenmiş göz, kaş, burun ve ağız tasvirlerinde çukur, çizgi ve kabarık formlardan faydalanılmıştır. Saçlar uzun ve başında üç dilimli sivri taç vardır.

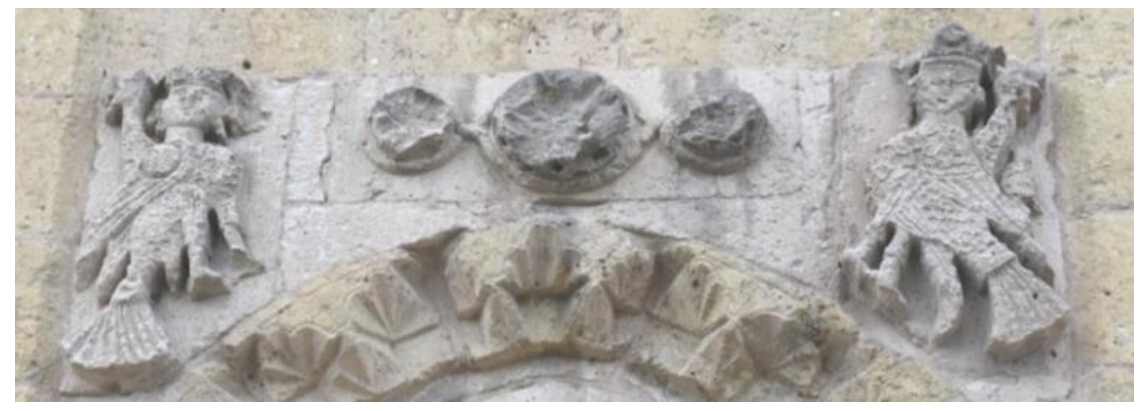

Fotoğraf 4, Çizim 4. Güneydoğu Cephe, Siren Figürleri.

\section{Arslan Figürlerinin Kuyruğunda Yer Alan Ejder Figürleri}

Arslan figürlerinin kuyruğunda yer alan ejder figürleri Hasankeyf Kalesi Küçük Saray, Ulu Beden Burcu, Kesikköprü Han, Hüdavend Hatun Kümbeti, Dazya (Gümüş Top) Köyü Zaviyesi ve Erçiş Zortul Kümbeti'nde yer almaktadır.

3a. Hasankeyf Kalesi Küçük Saray'ın (12. yüzy1l) (Altun, 1978: 211) kuzey ve güney cephe penceresinin üstünde profilden verilmiş, karşılıklı iki arslan figürü bulunmaktadır (Gierlichs, 1996: 256). Yüksek kabartma olarak işlenen figürlerin arasında kufi yazılı pano vardır. Oldukça detaylı tasvir edilen arslan figürleri açık ağızlı, sivri dişli ve badem gözlüdür. Figürlerin pençeleri iri, gövdesi heybetli bir şekilde işlenmiştir. Sağ ön ayakları yukarı doğru kalkıktır. Kas ve eklemleri belirgindir. Büyük ağzı, küçük kulakları çizgi ve kabartma formları ile ifade edilen figürlerin tasvirleri başarılıdır. Birbirlerine doğru yürür vaziyetteki arslanların kuyrukları arka bacaklarının arasından geçip gövdelerine doğru kıvrılmıştır. Kuyruklarının ucunda birer ejder başı bulunmaktadır. Ejder 
figürlerinin badem gözleri, açık ağızları, sivri dişleri, uzun dilleri, sivri kulakları derin çizgiler ve kabartma formları ile işlenmiş, saldırıya hazır durumda betimlenmiştir (Foto. 5, Çiz. 5).

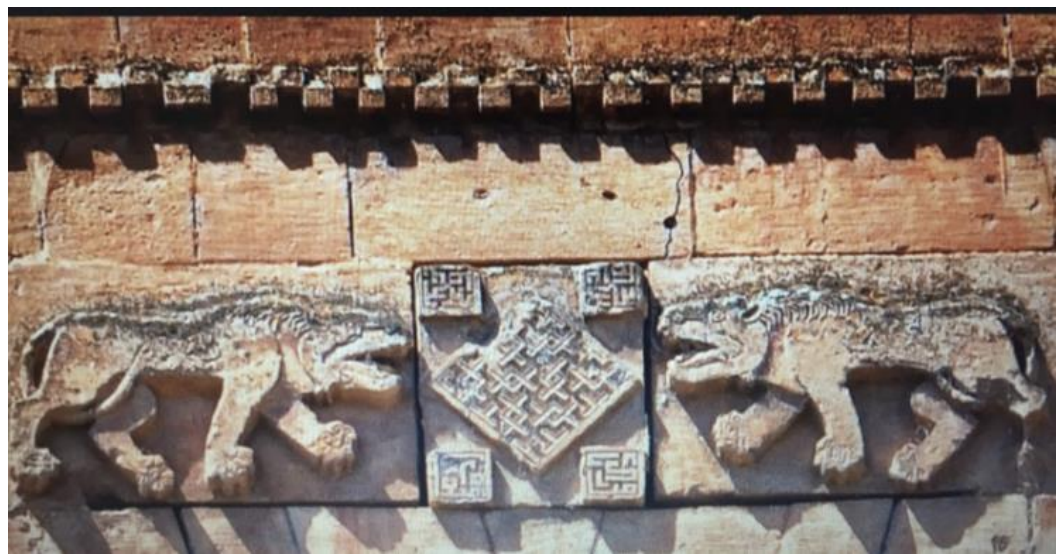

Fotoğraf 5. Arslan Figürleri, Ayrıntı.

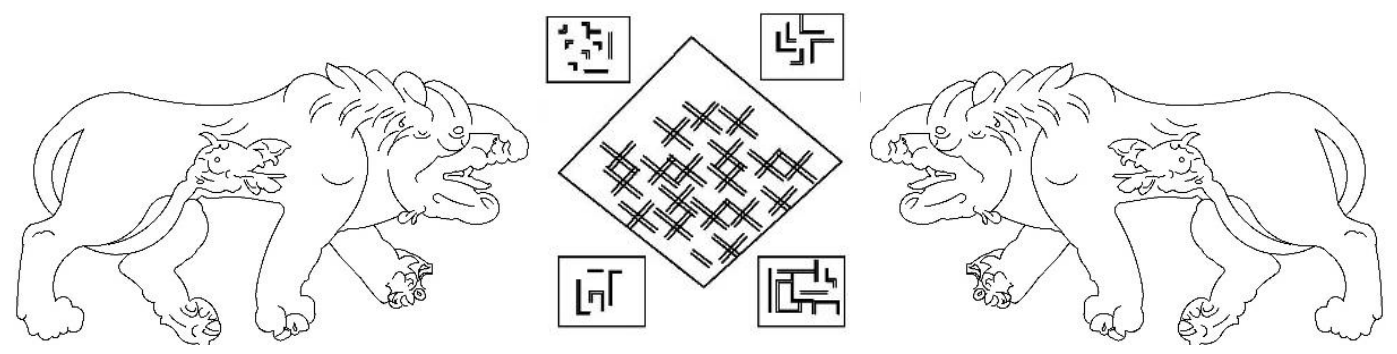

Çizim 5. Arslan Figürleri, Çizim.

3b. Diyarbakır Kalesi Ulu Beden Burcu'nun (H. 605/M. 1208) (Aslanapa, 1971: 17; Gabriel, 1993: 23) yüzeyindeki kitabenin ikinci satırının batı ve doğu tarafında, karşılıklı, gövdeleri ve başları cepheden verilmiş arslan figürleri yer almaktadır (Parla, 2016: 12) Figürlerin ön ayaklarının gövdeleri ile birleştiği yerlerden çıkan kanatları yelpaze şeklindedir. Yüksek kabartma olarak işlenmiş figürlerin kuyruklarının bitiminde profilden verilmiş ejder başları yer alır. Sivri kulakları ve yuvarlak iri gözleri seçilebilen figürlerin başlarının büyük bölümü tahrip olmuştur. Figürün havada olan ön bacaklarından birisi bükülmüş, eklemleri ve gövde kasları belirgindir. Pençeleri büyük ve belirgin parmak yoktur. Figürler başarılı tasvir edilmiştir (Foto. 6-7, Çiz. 6-7).
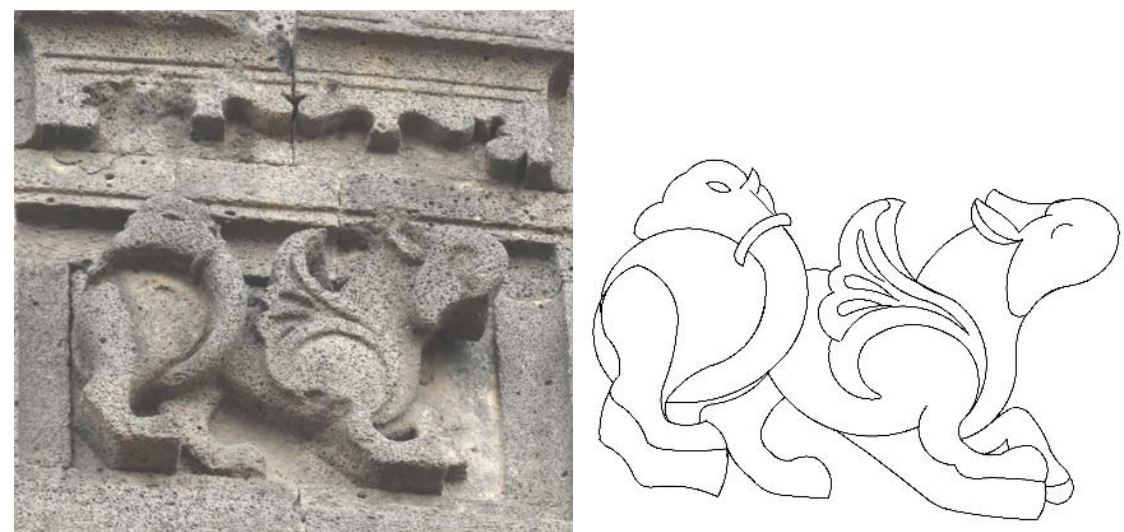

Fotoğraf 6. Çizim 6. Figür ve Çizimi. 

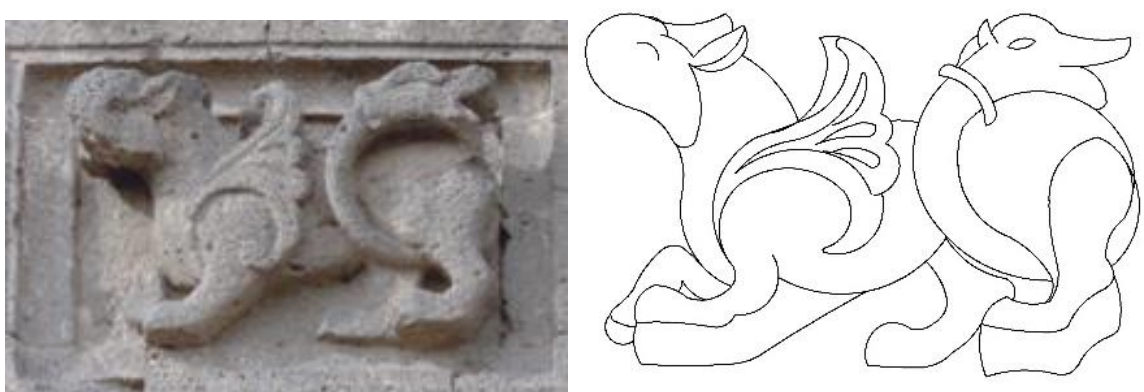

Fotoğraf 7. Çizim 7. Figür ve Çizimi.

3c. Kesikköprü Han (H. 667/M. 1268) (Şahin 2002: 483; Aslanapa 2007:129) kapalı bölüm taçkapısının güney ve kuzey tarafında iki arslan tasviri yer almaktadır (Öney, 1969a: 15). Alçak kabartma olarak verilen kuzey taraftaki arslan figürü yürür vaziyettedir. Başı cepheden verilmiş, iri ve yassı burunlu, dolgun yanaklı, küçük kulaklı ve iri gözlü arslan kısa bacaklıdır. Eklem ve gövde kasları çok belirgin değildir. Arka bacaklarının arasından yukarı doğru kıvrılan kuyruğunun bitimindeki profilden verilmiş ejder figürü iri gözlü ve sivri kulaklıdır. Çizgi ve kabartma formları ile işlenmiş açık ağzı ve sivri dişleri olan ejder, arslanın arka tarafındaki bir kuşu ile mücadele halindedir (Foto. 8, Çiz. 8). Kuzeydekine benzediği muhtemel olan güney taraftaki arslanın gövdesinin arka kısmı tamamen kırık durumda, yüzü de tahrip olmuş haldedir.
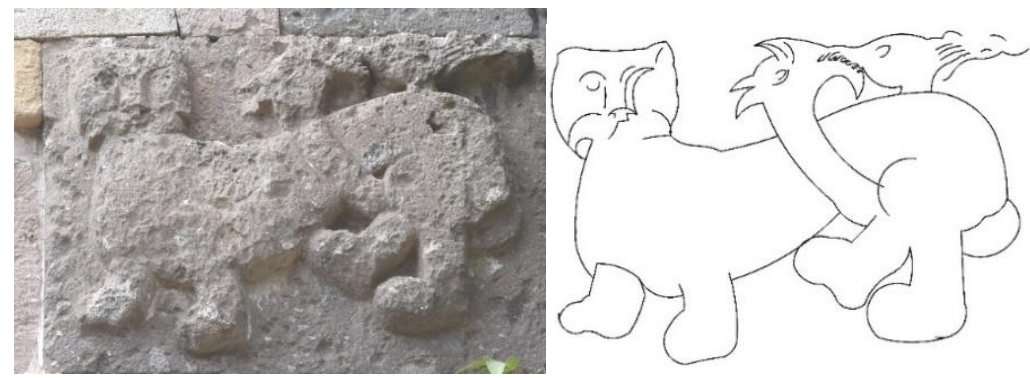

Fotoğraf 8. Çizim 8. Kesikköprü Han, Kapalı Bölüm Taçkapı Figürleri ve Çizimi.

3d. Dazya (Gümüş Top) Köyü Zaviyesi (H. 777/M. 1375) (Yurdakul, 1969: 245; Gündoğdu, 2004: 74) kapısının kemer üzengi taşı hizasında, kitabenin alt tarafında iki yanda birbirine dönük, profilden verilmiş arslan figürleri bulunmaktadır (Gündoğdu, 2004: 74-76). Batı tarafındakinin baş1 yukarı doğru kalkmış ve doğudakinin başı arkaya dönüktür. Pençe detayları belirgin değildir. Eklem ve kasları belirgin ancak detaylı işlenmeyen figürler alçak kabartma tekniği ile verilmiş olup, gövdelerinin üzerinden kendilerine doğru kıvrılmış kuyrukları ejder başı ile sonlanmaktadır. Batı taraftaki ejder başı diğerine göre daha büyüktür. Figürlerin ön bacaklarının gövdeye birleştiği yerlerde rumi bezemeler vardır (Foto. 9-10, Çiz. 9-10).
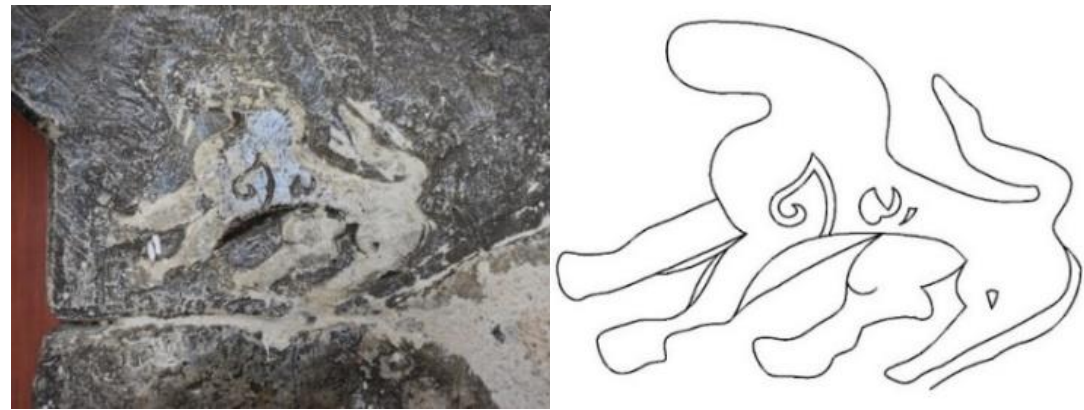

Fotoğraf 9, Çizim 9. Batı Taraf Figür ve Çizimi. 


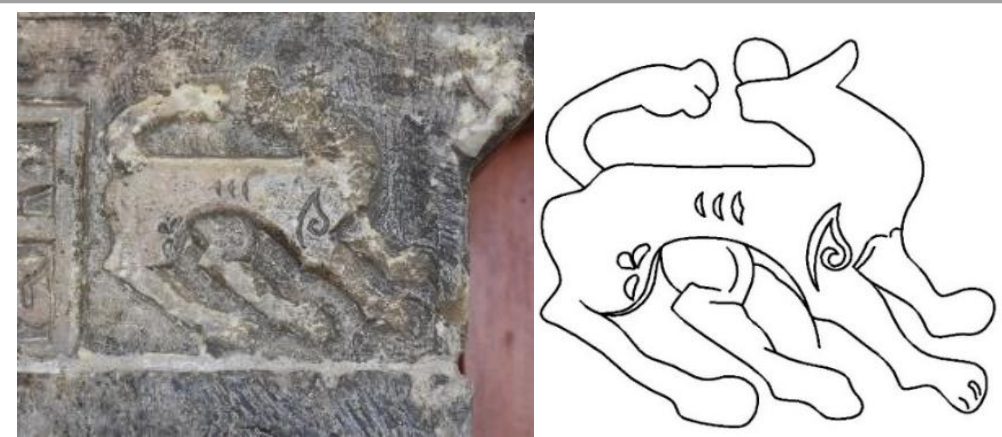

Fotoğraf 10, Çizim 10. Doğu Taraf Figür ve Çizimi.

3e. 15. yüzy1la tarihlendirilen (Asalanapa 1956: 106; Top 1999: 24-25; Bingöl, 2020: 35) Erçiş Zortul Kümbeti'nin kuzey cephesindeki pencerenin üzerinde profilden verilmiş arslan figürleri yer alır (Öney 1969c: 26). Alçak kabartma olarak işlenen figürler diğer yapılardaki arslan figürlerinden farklı olarak birbirine arkaları dönük ve oturur durumdadır. Eklem ve kasları belirgindir ancak çok tahrip olduğu için detaylar tespit edilememektedir. Batı taraftaki arslanın başı tamamen tahrip olmuş, diğerinin yüzü seçilememektedir. Ön ayakları öne doğru uzanır durumdaki figürlerin gövdelerine doğru çıkan kuyruklarının bitiminde ejder başları ağızları açık, saldıı halindedir (Foto. 11, Çiz. 11).

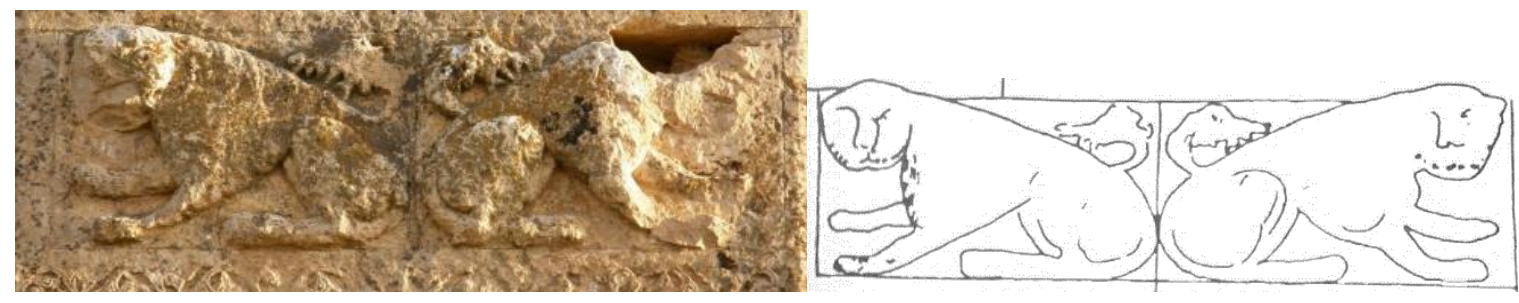

Fotoğraf 11, Çizim 11. Figürler ve Çizimi.

3f. Hüdavend Hatun Kümbeti'nin (H. 712-713/M. 1312-13) (Akalın, 1998: 284-285; Gabriel, 1999: 119; Önkal, 2015: 159; Özkarc1, 2007: 152) güneybatı cephesindeki pencere niş kemerinin üstünde simetrik olarak yerleștirilmiş karşılıklı arslan figürleri, arka ayakları üzerinde şaha kalkmıș durumda alçak kabartma olarak tasvir edilmiş̧ir. Gövde detayları çok başarılı işlenmeyen zayıf gövdeli bu figürler duruş pozisyonu ve üslup olarak diğer yapılardakilerden farklıdır. Arslanların arasında da dışa taşkın iki rozet vardır. Kuyruklarının bitiminde ejder başları bulunmakta ancak yüz detayları tespit edilememektedir. (Foto. 12, Çiz. 12).
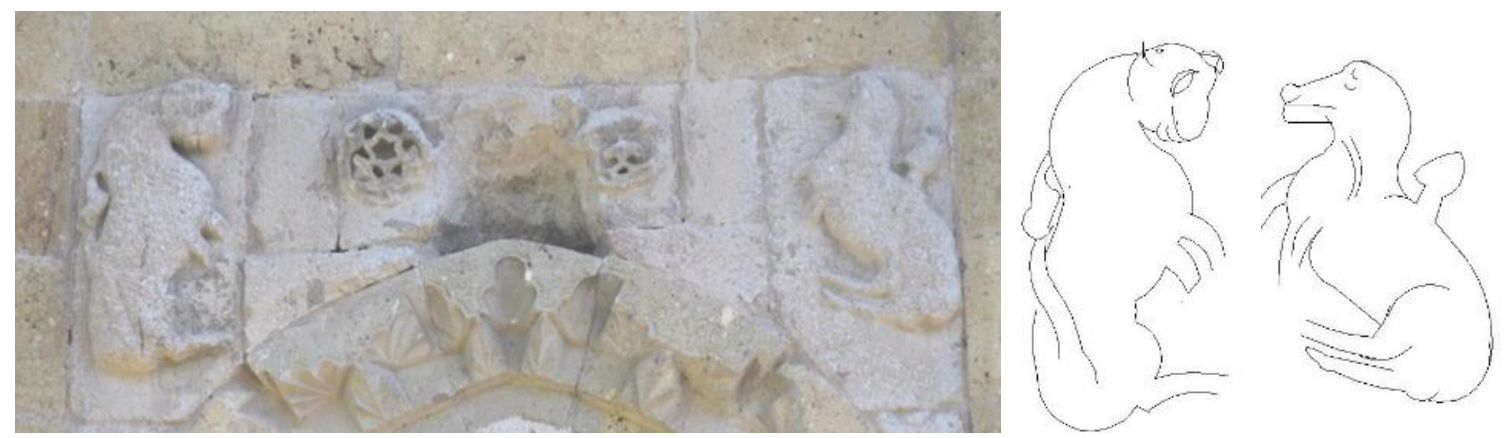

Fotoğraf 12. Çizim 12. Güneybatı Cephe, Arslan Figürleri ve Çizimi. 


\section{Ejder Figürlerinin Kuyruğunda Yer Alan Ejder Figürleri}

Tuzhisarı Sultan Han'1n (H. 630-634/M. 1233-1237) (Akok, 1969: 6; Özbek, 2007: 177; Denknalbant, 2009: 504) avlusunda bulunan köşk mescidin güney ve doğu kemer yüzeylerinde, başları kilit taşında karşılıklı, S şeklinde kıvrımlar oluşturan ejder figürleri vardır (Özbek, 2007: 177). Güney taraftaki birbirine dönük ejder figürlerinin ağzı açık ve volutludur. Sivri dişleri ve çatallı dilleri vardır. Sivri kulaklı, badem gözlü olan figürlerin yüz detayları çukur ve kabartma formları ile işlenmiş, oldukça başarılı tasvir edilmiştir. Buradaki figürlerinin tahrip olmuş kuyrukları mücadele halinde ejder başıyla sonlanmaktadır. Bu figürler çizgi ve kabartma formları ile işlenmiş ancak diğerleri kadar başarılı değildir (Foto. 13-14-15, Çiz. 13-14).
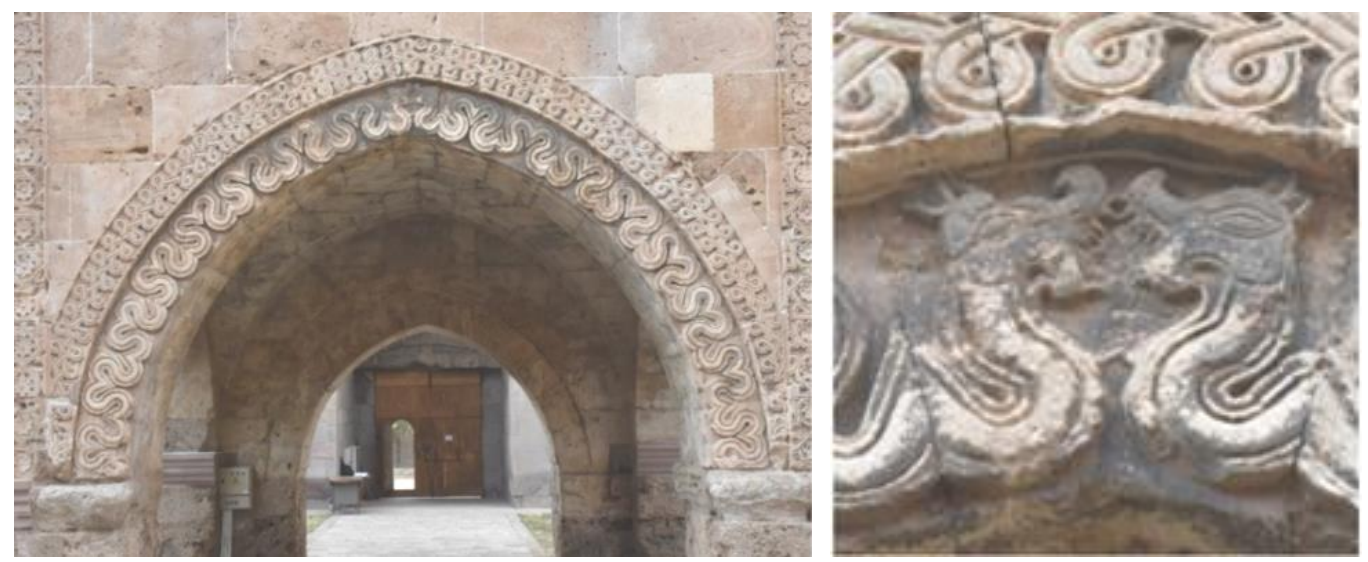

Fotoğraf 13. Güney Cephe, Ejder Figürleri.
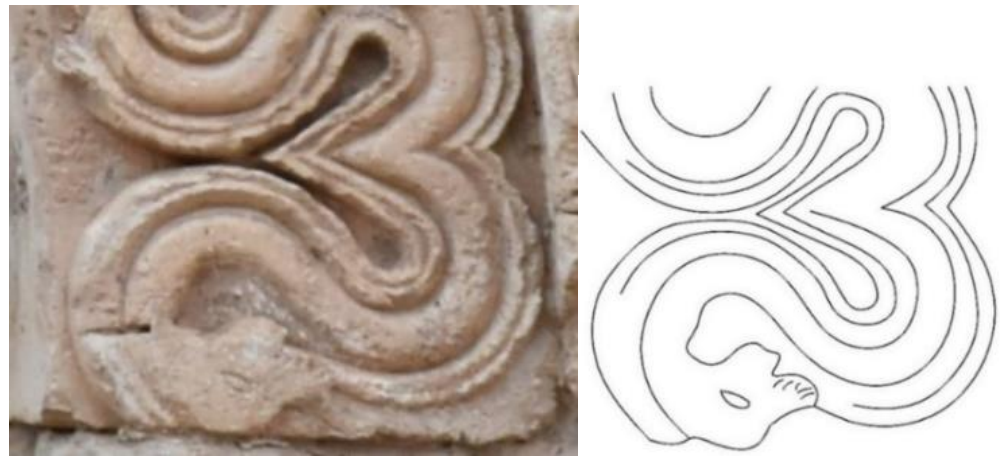

Fotoğraf 14. Çizim 13. Doğu Taraf Kuyruk ve Çizimi.
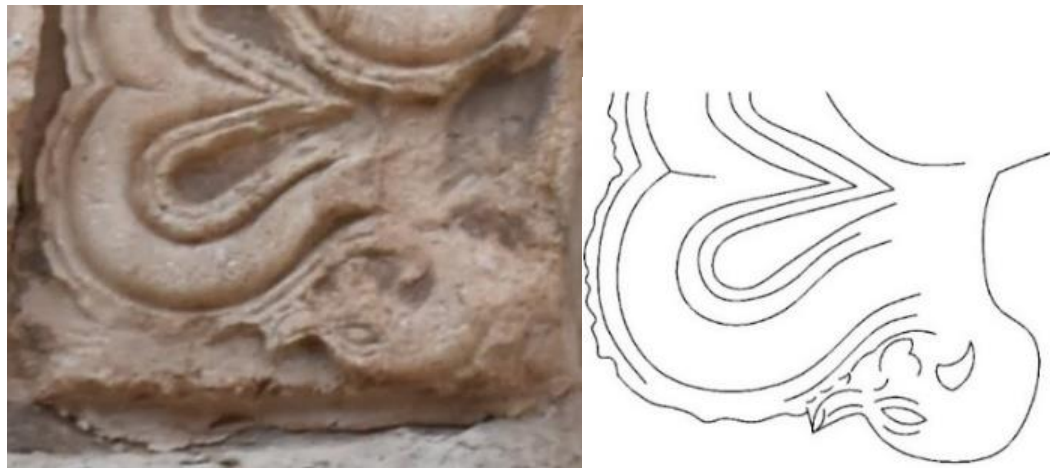

Fotoğraf 15. Çizim 14. Batı Taraf Kuyruk ve Çizimi. 


\section{Değerlendirme:}

Tablo 1. Ejder Kuyruklu ve Kanatlı Figürlerin Yer Aldığ 1 Yapılar

\begin{tabular}{|c|c|c|c|c|c|c|c|}
\hline No & Yapının adı & $\begin{array}{l}\text { Figür } \\
\text { Sayısı }\end{array}$ & $\begin{array}{l}\text { Figür } \\
\text { Yeri }\end{array}$ & Tarihi & Yeri & Dönemi & Yapı Tipi \\
\hline 1 & $\begin{array}{c}\text { Hasankeyf } \\
\text { Kalesi }\end{array}$ & 2 & Cephe & 12. yüzy1l & $\begin{array}{c}\text { Mardin } \\
\text { Hasankeyf }\end{array}$ & Artuklu & $\begin{array}{l}\text { Kale } \\
\text { (saray) }\end{array}$ \\
\hline 2 & $\begin{array}{c}\text { Küçük Saray } \\
\text { Ulu (Evli) } \\
\text { Beden }\end{array}$ & 3 & Cephe & $605 / 1208$ & Diyarbakır & Artuklu & Kale \\
\hline 3 & $\begin{array}{c}\text { Divriği Ulu } \\
\text { Cami } \\
\end{array}$ & 2 & $\begin{array}{c}\text { Taçkapı } \\
\text { Yanı }\end{array}$ & $626 / 1228-29$ & Sivas & Mengücekler & Cami \\
\hline 4 & $\begin{array}{c}\text { Tuz Hisarı } \\
\text { Sultan Hanı }\end{array}$ & 2 & $\begin{array}{c}\text { Köşk } \\
\text { Mescit }\end{array}$ & $\begin{array}{c}630- \\
634 / 1233- \\
1237 \\
\end{array}$ & Kayseri & $\begin{array}{l}\text { Anadolu } \\
\text { Selçuklu }\end{array}$ & Kervansaray \\
\hline 5 & $\begin{array}{c}\text { Kesikköprü } \\
\text { Han }\end{array}$ & 2 & $\begin{array}{l}\text { Pencere } \\
\text { Taçkap1 }\end{array}$ & $667 / 1268$ & Kırşehir & $\begin{array}{l}\text { Anadolu } \\
\text { Selçuklu }\end{array}$ & Kervansaray \\
\hline 6 & $\begin{array}{l}\text { Hüdavend } \\
\text { Hatun } \\
\text { Türbesi }\end{array}$ & 5 & Cephe & $\begin{array}{c}712- \\
713 / 1312-13\end{array}$ & Niğde & İlhanlı & Kümbet \\
\hline 7 & $\begin{array}{c}\text { Dazya Köyü } \\
\text { Zaviyesi }\end{array}$ & 2 & Kap1 & $777 / 1375$ & $\begin{array}{c}\text { Tokat } \\
\text { Turhal } \\
\end{array}$ & Eretna & Medrese \\
\hline 8 & $\begin{array}{c}\text { Erçiş Zortul } \\
\text { Kümbeti }\end{array}$ & 2 & Pencere & 15. yüzyıl & Van & Karakoyunlu & Kümbet \\
\hline
\end{tabular}

Yaptığımız çalışma ve incelemeler ışığında 20 ejderli figür tespit edilen 8 yapının 2'si kale, 2'si kervansaray, 1'i cami, 1'i zaviye ve 2'si kümbettir. Yapıların 2'si Artuklu, 2'si Anadolu Selçuklu, 1'i İlhanlı, 1'i Eretna, 1'i Mengücek, 1'i Karakoyunlu dönemine aittir. Yapıların 4'ü İç Anadolu, 2'si Güneydoğu Anadolu, 1'i Doğu Anadolu, 1'i Karadeniz bölgesinde bulunmaktadır. Figürler yapıların dış cephelerinde kolay görülebilecek şekilde tasvir edilmiştir (Tablo 1). Selçuklu stilindeki figürler yukarıda detaylı olarak verildiği gibi dönemin özelliklerini taşımaktadır.

Asya kozmoloji ve mitolojisinde önemli yeri olan ejder figürü Türk sanatına Çin'den geçmiştir. Eski Türkçede "büke”, “evren”, "luu”, "nek”, "kök-luu” olarak da adlandırılır (Özkeçeci, 2007: 108; Esin, 1979: 43) Figürün kökenlerinin Sümerlere kadar gittiği bilinmektedir ve Eski Mısır'da krallı̆̆ 1 temsil eder (Keskiner, 2007: 50). Kompozisyonlarda sık görülen ejder tasvirleri üç şekildedir. Avrupa'da Heraldik "rampant" olarak adlandırılan bir stilde iki ejder karşı karşıya ayaktadır. Fransız sanat tarihçilerinim arc d dragons (evren tâkı) olarak isimlendirdiği ikinci stil; gövdesinin her iki tarafında bir başı olan ejder, gökyüzünün tâkını temsil eder. Bu üslup, hem Çin'de, hem Kuşan dönemi taht süslemelerinde ve Türk sanatında da vardır. Üçüncü stilde bir veya iki çift evren birbirine veya ağaca sarılarak düğümlenir (Esin, 1969: 166). Ejder figürleri İslam sanatında Türklerin İran ve Ön Asya'ya gelmesiyle yaygınlık göstermiştir. Bu zaman zarfında figürler sürünür vaziyette, pullu gövdeli olarak tasvir edilmiş, zamanla kanat ve ayak ayrıntıları ilave edilmiştir. Dört ayaklı ejderler yoğun olarak Moğol istilasından sonra görülmeye başlamıştır. Bu figürler eserlerde sivri dişli, boynuzlu, iri gözlü ve keskin ağızlıdır. Figür başka figürlerle ya da ikili olarak betimlendiği gibi sadece başı olan tasarımlar da vardır (İnal, 1971: 157-158).

Türk mitolojisi ve sanatında önemli figürlerden birisi olan ejder, Uygur sanatında da tasvir edilmiştir. 9-10. yüzyıllarda Doğu Türkistan'da inşa edilmiş olan 19. tapınaktan alınarak Berlin'e götürülen bir Bezeklik freskosunda kanatları rumi şeklinde, pullu, ağzı açık ve pençelerini yukarıya 
kaldırmış, suyun altından çıkıp göğe doğru yükselen bir gök ejderi tasviri yer almaktadır. Detaylı olarak resmedilmiş kompozisyonun arka planında çeşitli hayvan tasvirleri, dağlar, ağaçlar ve bitkiler bulunmaktadır. Fügürün bulutlar arasına yerleşerek yağmur yağmasına sebep olan olan bolluk ve bereket sembolü olduğu düşünülmektedir (Çoruhlu, 2011b: 295) (Foto 16).

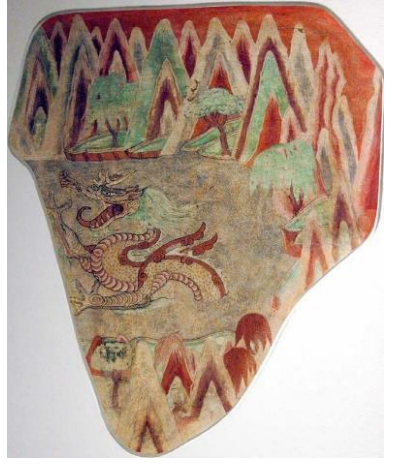

Fotoraf 16. Bezeklik 19. Tapınakta Ejder Figürü. Berlin Staatliche Museum, Env. No: 1 B 8383

(Çoruhlu 2011b: 295- 503).

Tuketa Kurganı'ndan çıkan ahşap bir madalyon üzerinde iki ejderin çevirdiği gök çarkı kompozisyonunun (Rudenko, 1968: 29) (Foto 17a) bir benzeri Konya İnce Minare Taş ve Ahşap Eserler Müzesi'nde sergilenen Konya Kalesi'ne ait taş üzerinde de bulunmaktadır (Foto 17b).

Orta Asya'nın doğusunda yaşayan Türklerde su kaynaklarını, yağmur bulutlarını simgeleyen astrolojik bir unsur olan figür, iyilik, kötülük, sağlık, yiğitlik sembolüdür (Öney, 1992: 48-49). Türk mitolojisi ve Çin mitolojisindeki Gök ejderi su, verimlilik, bereket ve canlanmayı sembolize eder. Yılana benzeyen yer ejderinin suların veya yerin derinliklerinde yaşadığ 1 ve kış mevsimi bitince yeryüzüne çıkarak, doğanın enerjisini yenilediği düşünülür. Türk Budist metinlerinde de gök gürültüsü ve yağmuru temsil eden figür, tabiatı ve dünyay1 simgelerken felek ve zaman gibi unsurlarla birlikte Felek çarkını çevirerek gece ve gündüzü oluşturur (Öney, 1992: 48-49; Özkeçeci, 2007: 108-109).

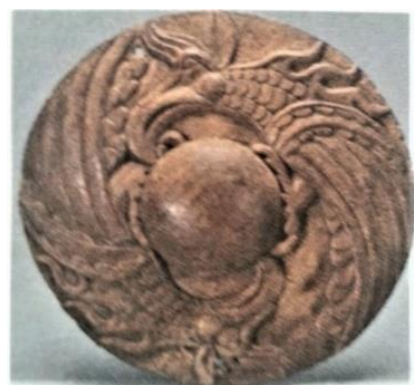

Fotoğraf 17a. Tuketa Kurganı Ejder Figürü (Rudenko, 1968).

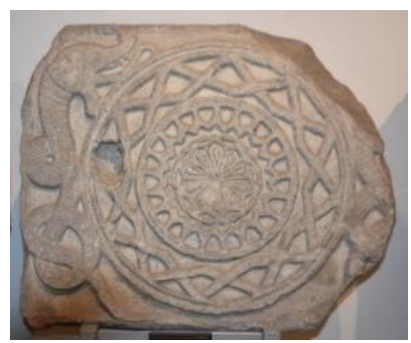

Fotoğraf 17b. Konya Kalesi Ejder Figürü, Konya İnce Minare Taş ve Ahşap Eserler Müzesi Env. No: 5817 (Saklavc1, 2017). 
İslâm kültüründe önemli yeri olan ejder figürü birçok kültür ve devirde taş, çini, maden, minyatür sanatlarında süsleme unsuru olmuş, taş işçiliğinde özellikle, şifahanelerde iyilik ve şifa sembolüdür. Tıp simgesi olan ejder tasarımları kale, han, saray gibi sivil mimari yapılarında düşman ve hastalıktan koruyan tılsımlar olarak yerleştirilmiştir (Öney, 1992: 46-47).

I. Alâeddin Keykubad'ın eşi, Mahperi Huand Hatun tarafından H. 636/ M. 1238-39 tarihinde yaptırılan Tokat Pazar Mahperi Hatun Kervansarayı çeşme lülesi ejder figürü şeklinde tasvir edilmiştir. Figür ağzının üst kısmı yukarıya kıvrık ve açık, badem gözlüdür. 1965 yılında kaybolan figür 1977 yılında Yozgat Müze'si koleksiyonuna dâhil edilmiştir (Acun, 1993: 263-266) (Foto 18).

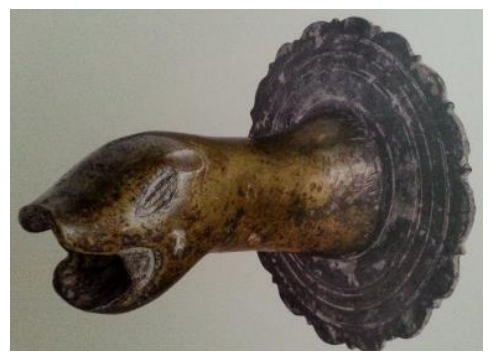

Fotoğraf 18. Tokat Pazar Mahperi Hatun Kervansarayı Çeşmenin Lülesi, Yozgat Müzesi, Ejder Figürlü Çeşme Lülesi Env. No: 335 (Bozer, Çeken, 2016: 494).

Ejder figürü minyatürlerde de yer almış, Saltukname, İskendernâme, Battalnâme gibi menkıbelerde yılan ve ejder şeklinde betimlenmiştir. Hz. Muhammed'in mucizeleri arasında ejder ile konuşması ve bir ejderi iki dağ arasına sıkıştırması gibi rivayetler bulunmaktadır (And, 2015: 323). Acaâibü'l-Mahlûkat'ta ejder takımyıldızı Tinnin olarak tasvir edilmiştir (And, 2015: 327-328) (Foto 19a). Zübdetü't Tevârih'in üç cildinde Hz. Musa'nın asasını ejdere çevirmesi anlatılmaktadır (And, 2015: 167) (Foto 19b). Siyer-i Nebi'de de Hz. Muhammed'in kervanının yolunu kesen ejder ile konuşması resmedilmiştir (Tanındı, 2006: 18) (Foto 19c).
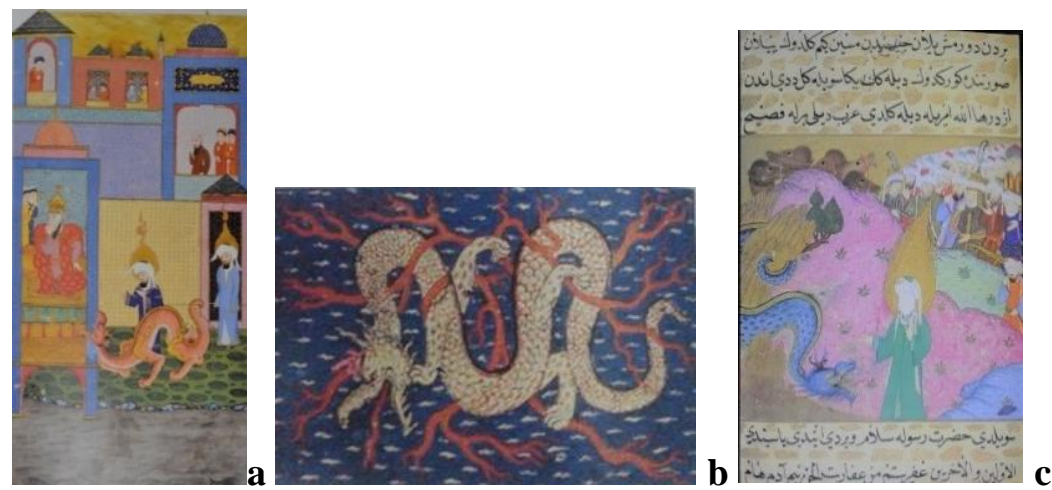

Fotoğraf 19 a. Hz. Musa'nın Asâsının Yılana Dönüşme Sahnesi, Zübdetü’t Tevârih TİEM 1973, (And, 2015).

b. Ejderha Takımyıldızı (Tinnin), Acaâibü'l-Mahlukat, Bl Add.7894 (And, 2015).

c. Hz. Muhammed'in Kervanının Yolunu Kesen Ejderha ile Konuşması, Siyer- i Nebi (Tanınd1, 2006: 18).

Çalışmamızda incelediğimiz kuyrukta yer alan ejder başının önde giden vücuda dönük durması, saldırması ve 1sırması Selçuklu stili ejder figürlerinin özelliklerinden birisidir (İnal, 1971: 157-158). Kuyrukta birbirini kovalayan figürün önde gideni 1sırma sahnesine, Eurasia göçebe sanatında sık rastlanmaktadır. Aksaray ve Kayseri'de M. 1270 yılında Farsça-Arapça Türkçe 
kelimelerin yer aldığı bir büyü kitabı yazarak süsleyen Nâsiruddî n Sivasî’ye göre, Kavos (kova) burcunun sembolü olan kentaur figürünün (Foto. 20a-b.) ejder şeklindeki kuyruğu, ön kısmında ok atan kentaur figürü ile mücadelesinin bir ikilik anlamına geldiği söylenebilir (Esin, 1969-70: 177). XII. yüzyılda Artuklu döneminde yapıldığı kabul edilen Cizre Köprüsü'nün (Çulpan 1970: 88-89; Özkan 1993a: 40) ayakları üzerinde yer alan sekizinci panoda da burç sembolü olan ejder ve kentaur figürleri birlikte verilmiştir (Foto. 20c.)
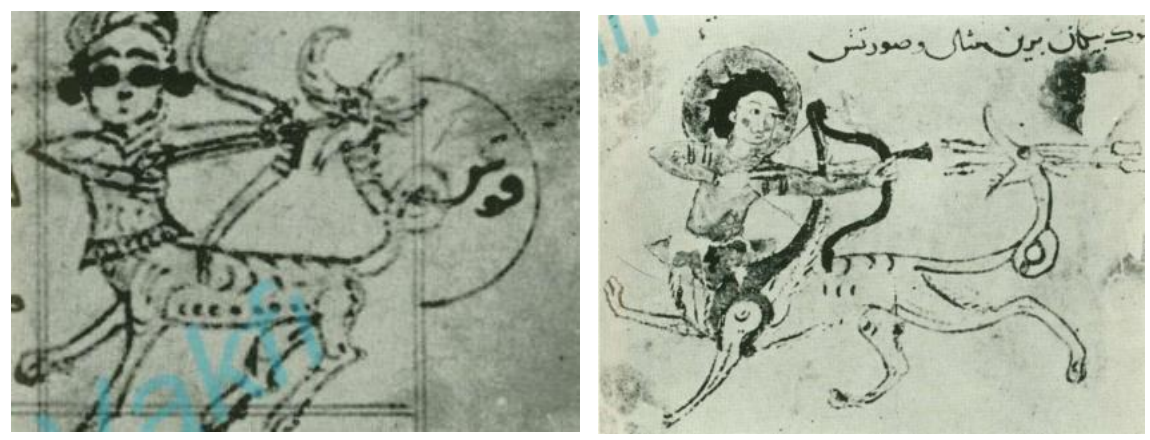

Fotoğraf 20a.b. Ejder Kuyruklu Kentaur Figürleri (Esin, 1969-70).

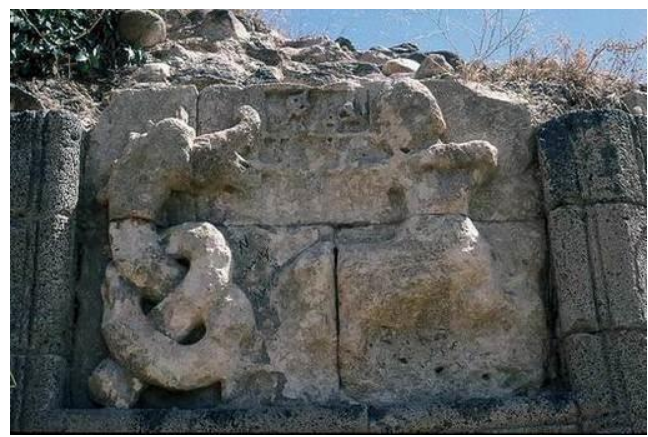

Fotoğraf 20c. Cizre Körüsü Ejder ve Kentaur Figürleri (Nicolle 2013). http://journals.openedition.org/beo/1404

Türkistan'daki erken Uygur eserlerinden, 8. yüzyıla ait olduğu düşünülen Çikan Köl duvar resminde balık gövdeli, pars veya arslan başlı bir ejder bulunmaktadır. Oğuzların Peçenek boyuna ait Nagy-Szent-Miklos'da bulunan Türkçe yazılı altın kapların birindeki pars veya arslan başlı ejder figürü Kuşan dönemi Amu-Derya örneğine benzemekte, Peçeneklerin Kuşan devrinde Batı ve Güney Türkistan etkisine göstermektedir (Esin, 1969-70:169) (Foto. 21).

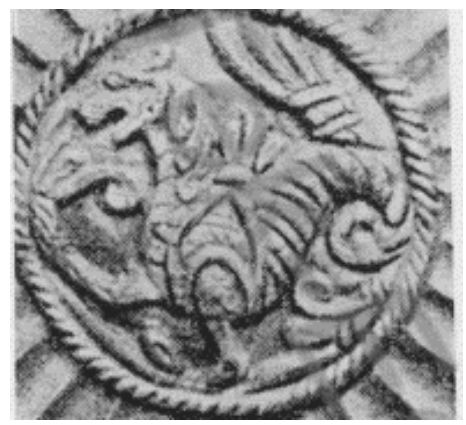

Fotoğraf 21. Arslan Başl1 Ejder Figürü (Esin, 1969). 
Göçebe Türkler arasında, Altın Yiş ve Teti-su'da ejderin kozmik anlamları alplik timsali olarak ve eski Eurasia göçebelerinin teknik ve stilinde gelişmiştir. Orkun yazıtlarında "alp" anlamına gelen "büke" kelimesinin bu üslûba karşılık geldiği söylenebilir. Bu ejderlerin Selçuklu sanatındaki özelliği, başlarının timsahdan çok "buri" başına benzemesidir. Ordos bölgesinde tespit edilen ve MÖ 6-5. yüzyıllara ait bronz figürlerin arasında kuyruk ve gövdelerindeki figürlerle mücadele halinde figürler bulunmaktadır. Bu kompozisyonlarda figürler gövde ve kuyruklarındaki diğer figürleri ısırır vaziyette tasvir edilmiştir. Ordos levhalarında, Sibirya göçebe sanatında Partfie bayraklarının üstünde, Köktürk devri Türkistan duvar resimlerindeki bayraklarda, ejder başı olarak tekrar eden "buri" maskesi, Köktürklerin bayrağında ve Uygur duvar resimlerinde de bulunmaktadır (Esin, 1969: $168)$.

Ejder mücadele sahneleri Selçuklu sanatında uygulanan tasvirler arasındadır (Esin, 196970: 171). Çalışma yaptığımız döneme ait arslan- ejder, ejder mücadelelerin Konya İnce Minare Taş ve Ahşap Eserler Müzesinde sergilenen ejder mücadelelerinde olduğu gibi Oğuz ve Uygur dönemi etkilerini gösterdiğini söylemek mümkündür. Müzeye Selçuklu dönemi yapılardan getirilen parçalar üzerinde kuyruklarında ikinci bir ejder olan mücadele sahneleri yer almaktadır. Bunlardan birisinde, vücudu düğümlü ve ağZı açık olan figürler bitkisel bezemeler arasında profilden verilmiştir. Figürlerin başı Emel Esin'in belirttiği gibi timsah başlarını andırmaktadır (Foto. 22). Çin'de ve Türklerde "luu" çeşitli şekillerde tasvir edilir. Bu şekiller, yılan ile timsaha benzer bir figürün başka hayvanlarla birleşmesinden meydana geldiği düşünülür. "Luu" tasvirleri geçmiş inanışların izlerini taşımaktadır. Mevsime göre atalarından birisi olan kuş gibi gökte uçar. Ejder tasvirlerinin bazılarındaki kanatların bu özellikten kaynaklandığına düşünülebilir. Son bahardan sonra ise, timsah ve su yılanı gibi sulara ve yer altına girer (Esin, 1969: 162).

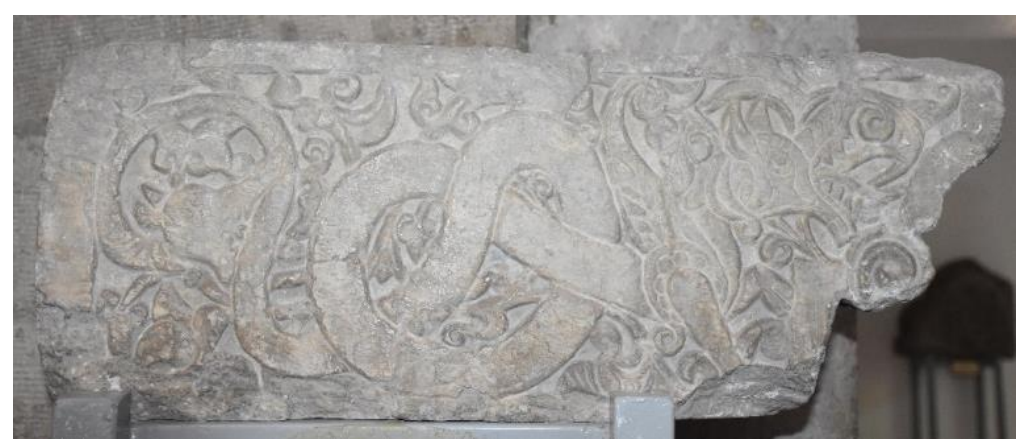

Fotoğraf 22. Konya Kalesi, Ejder Figürü, Konya İnce Minare Taş ve Ahşap Eserler Müzesi Env. No: 1394 (Bozer, Çeken 2016: 54 ) (Saklavc1, 2017).

Başka bir taşta profilden verilmiş, arslan başı ve ayaklarını andıran figürün vücudu düğümlü açık ağızlı ve dili dışarıdadır. Kanatları olan figürün kuyruğunda bulunan ejder başı gövdesini 1sırmaktadır (Foto.23).

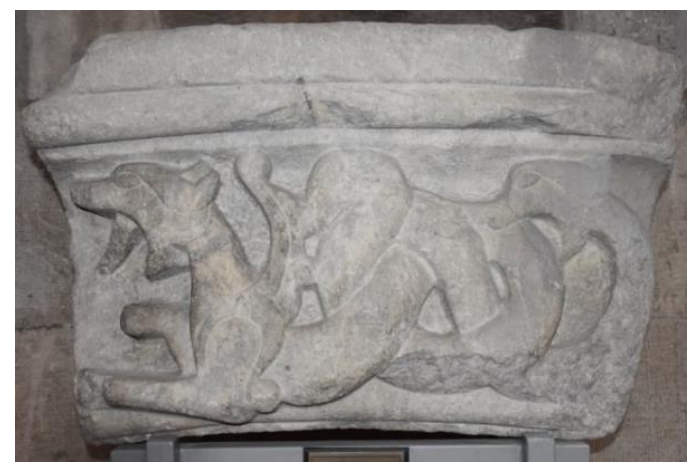

www.turkishstudies.net/turkishstudies 
Fotoğraf 23. Konya Kalesi, Ejder Figürü, Konya İnce Minare Taş ve Ahşap Eserler Müzesi Env. No: 890 (Bozer, Çeken 2016: 58) (Saklavc1, 2017).

Bir diğer figür bitkisel bezemeler içerisinde tasvir edilmiş, profilden verilmiş, vücudu düğümlü ve ağzı açıktır. Kanatları bulunan figürün ayakları ve başı kurt ya da köpeğe benzemekte, kuyruğunda bulunan diğer başı gövdesini 1sırmaktadır. Figürlerin dilleri çatal şeklindedir (Foto. 24).

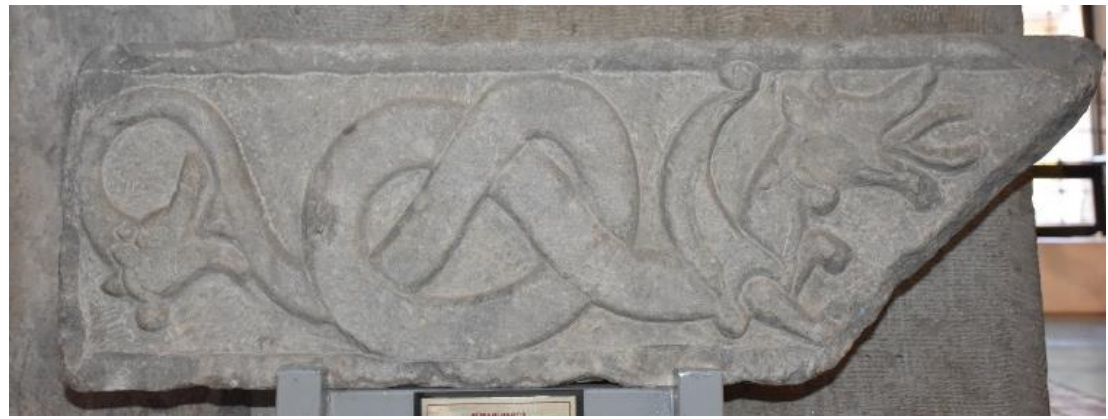

Fotoğraf 24. Konya Kalesi Ejder Figürü, Konya İnce Minare Taş ve Ahşap Eserler Müzesi Env. No:889 (Bozer, Çeken, 2016: 60). (Saklavc1, 2017).

Kars Müzesi'nde yer alan, Ani'den getirilen bir taş üzerinde gövdesi profilden, başı cepheden verilmiş gövdesi arslan, başı insan, kuyruğu ejder şeklinde figür tasvir edilmiştir. Figürün gözleri badem şeklinde, iri burnu yassı ve uzun, ağzı küçük, kulağı büyük ve uzun saçlıdır. Başındaki taçta helezonik süslemeler vardır. Oturur vaziyetteki figürün ön ayağının gövdeye birleştiği yerden rumi kıvrımlı kanat çıkmaktadır. Arka bacaklarının arasından çıkıp yukarı doğru kıvrılan kuyruğunda ağzı açık, sivri ve iri dişli başını ısırmaya hazırlanan profilden bir ejder figürü görülmektedir. Selçuklu stilinde tasarlanan ejderin kulakları dik ve büyüktür (Foto. 25a-b).
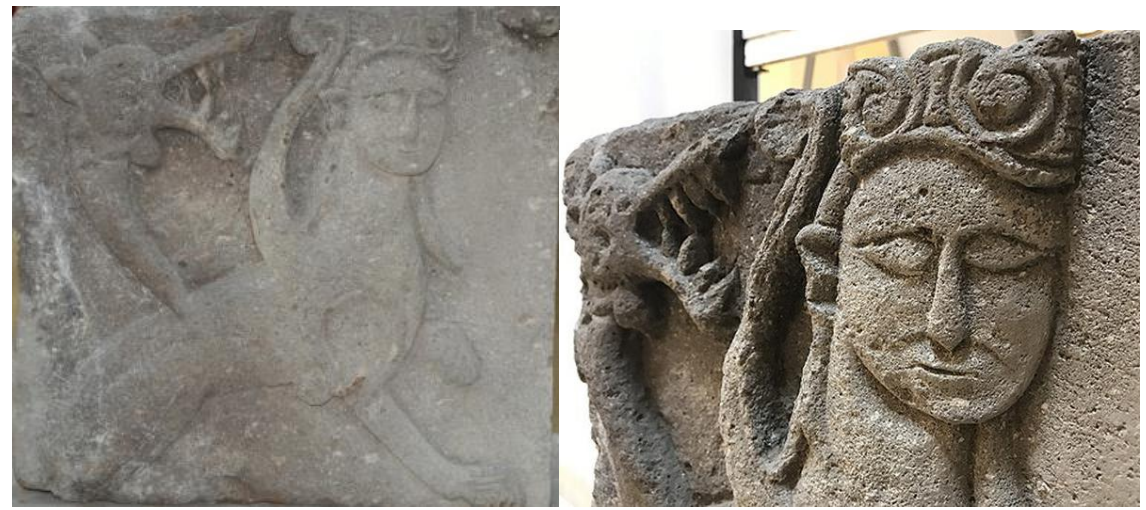

Fotoğraf 25a-b. Ani Katedrali Figürü, Kars Müzesi. (https://www.haberler.com/ani-de-kazicalismalarinda-bulundu-muzede-9911639-haberi/22.01.2020).

Artuklular zamanında, 12. yüzyılın başlarında Şırnak'ın Cizre ilçesinde inşa edilen Cizre Ulu Cami'nin kapı tokmağında da profilden verilmiş, simetrik, başları gövdelerine doğru dönmüş, iki ejder figürü tasarlanmıştır. Ejderlerin vücutları düğümlü, sivri kulaklı, badem gözlü, açıkağızlı, kuyrukları birbirine dolanmış vaziyettedir. Başlarının arasında arslan başı vardır (Foto. 26). Kanatlarını ısırmaya çalışan figürlerin kuyruklarının ucundaki Avrasya stili kartal başları kuyruğu ısırır vaziyettedir (Öney, 1969b: 178). Kapı tokmağının ejder figürlü parçaları, yurt dışına çıkarılmış ve David Koleksiyonu'na dahil edilmiş, 38/1973 envanter numarası ile kaydedilmiştir. Figürlerden birisi İstanbul Türk ve İslâm Eserleri Müzesi'ne teslim edilerek 3749 ve 3750 envanter numaraları ile koruma altın alınmıştır (Karaduman, 2005: 485). 


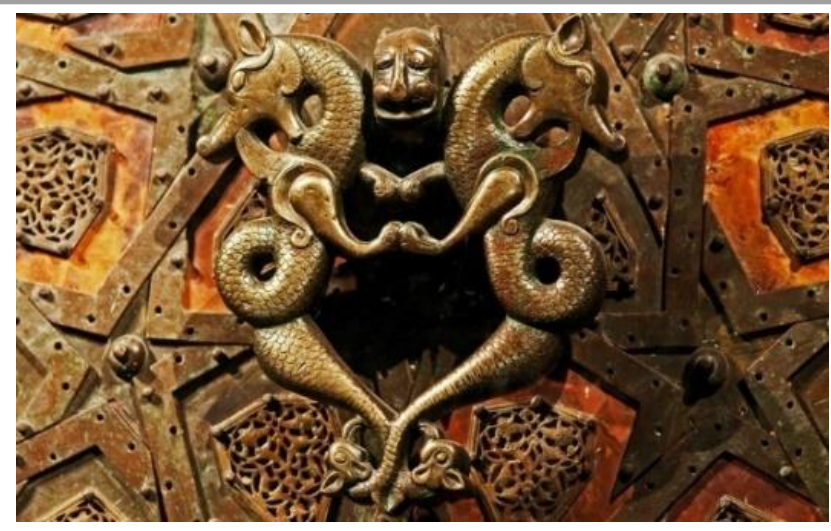

Fotoğraf 26. Cizre Ulu Cami, Bronz Ejder Figürleri (Karaduman, 2005: 493).

Kubad Abad Küçük Saray'da 1992 kazılarında çıkarılan sıraltı tekniği ile yapılmış bir yıldız çinide tasvir edilen sfenks figürünün de kuyruğu ejder ile sonlanmaktadır. Arkaya dönük başının çevresinde oval bir hale ve başlığında tüy seçilebilen figürün ön ayağının gövdeye birleştiği yerden rumi kıvrımlı kanat çıkmaktadır. Yukarı doğru kıvrılan kuyruğunda ağzı açık, sivri ve iri dişli başını 1sırmaya hazırlanan profilden bir ejder figürü görülmektedir. Selçuklu stilinde tasarlanan ejderin kulakları dik ve büyüktür (Foto. 27).

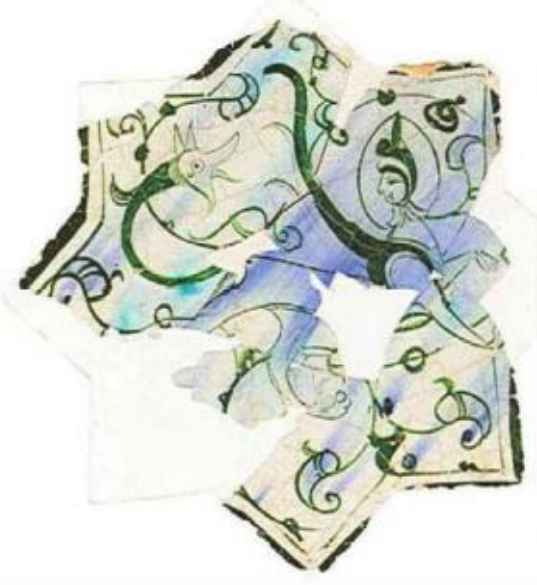

Fotoğraf 27. Kubad Abad, Küçük Saray, Sfenks Figürlü Yıldız Çini, Konya Karatay Müzesi (Arık, 2007: 313).

Anadolu inanışlarındaki Bektaşî menkıbelerinin bazılarında ejderha donuna girildiği görülür. Türklerin eski dinleri ve mitolojik unsurlarla şekillenen ve korkulan bir sembol olan ejder figürü bu menkıbelerde veliye duyulan saygı ve onun manevi gücünü temsil eder. Ejder figürleri kuvvet, mücadele, iyilik-kötülük gibi özellikleri ile velilerin kerametlerine ve dini hâkimiyetinin kabul edilmesinde etkili olmuştur. Veliler bu hikâyelerde ejder suretine bürünür, ejderi öldürür veya elindeki asayı ejderhaya dönüştürür. Böylece cezalandırıcı ya da kâfirleri Müslümanlığa döndüren bir karakterler haline dönüşür (Ocak, 2013: 226-228; Saklavc1, 2015: 56-60; Yücel, 1997: 115-120).

$\mathrm{Bu}$ inançların etkileri sonucu ayna, nefir, alem, ve keşkül gibi çeşitli tarikat eşyalarında da ejder figürleri tasvir edilmiştir. Figürler tasavvuf inancına göre insanın bütün kötülüklerin kaynağı olan nefsini terbiye etmesi ve kâmil insan olmaya çalışması olarak da değerlendirilebilir (Çevrimli, 2012: 211). 13. yüzyılın ilk yarısına ait bir aynayı çevreleyen bandın en üstünde birbirinin gövdesini 
1sırmaya çalışan, kuyrukları düğümlü, gövdeleri pullu, ayaklı, kanatlı, yeleli, ağızlar açık, ağızları dışa kıvrık iki ejder figürü yer almaktadır (Çevrimli, 2012: 201) (Foto. 28). Aynadaki ejder figürleri simgesel olarak suret ve gerçeğin aynı olması, tevhit inancı, kendi varlığını Allah'ın varlığında yok ederek 'bir' olma kavramları olarak değerlendirilmektedir (Bağc1, 1996: 16-24). Bu açıklamının ışığında gövdeden çıkan, ısırmaya ya da saldırmaya hazırlanan ejder tasarımlarının insanın kendi kendisi ve nefsi ile mücadelesini temsil ettiğini söylemek de mümkündür.
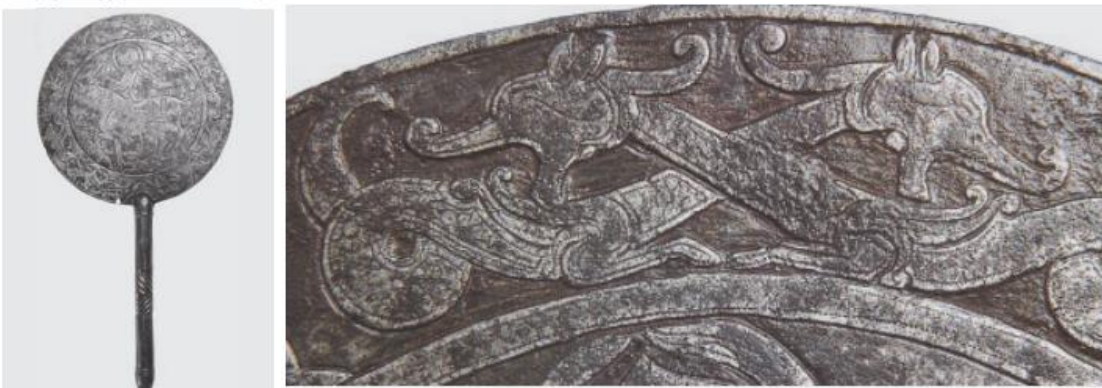

Fotoğraf 28. Ejder Figürlü Ayna TSM Env. No. 2/1792 (Çevrimli, 2012).

Bektaşi tarikat eşyaları arasında ejder en çok kullanılan figürlerden birisidir. Dervişlikte önemli bir ritüel dilenmedir. Dervişler dilenirken fakirlik ve dünya hayatından vazgeçmeyi temsil eden keşküllerle yapılır (Altıer, 2008: 104-107). Hacı Bektaş Müzesi'nde yer alan bu keşküllerden birisinin kulplarında Selçuklu stili ejder başları tasvir edilmiştir (Foto. 29).

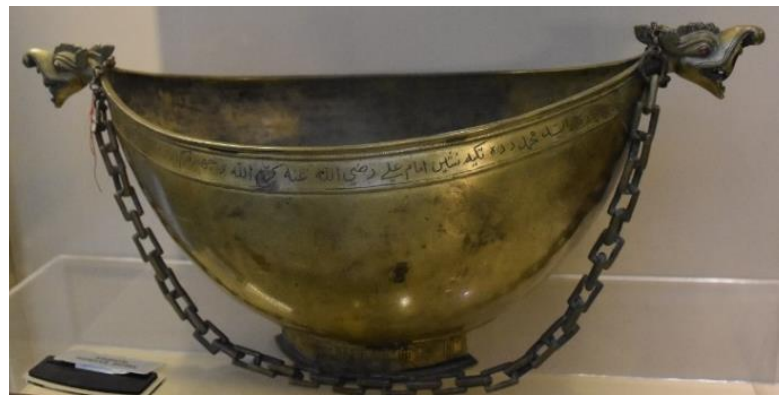

Fotoğraf 29. Ejder Kulplu Bakır Keşkül, Hacı Bektaş Müzesi, Env. No: 828 (Saklavcı, 2018).

Konya Mevlana Müzesi ve Hacı Bektaş Müzesi’nde de 19. yüzyıla ait dervişlerin haberleşme amacıyla kullandıkları ejder figürlü nefirler yer almaktadır (Foto. 30a-b-c.)
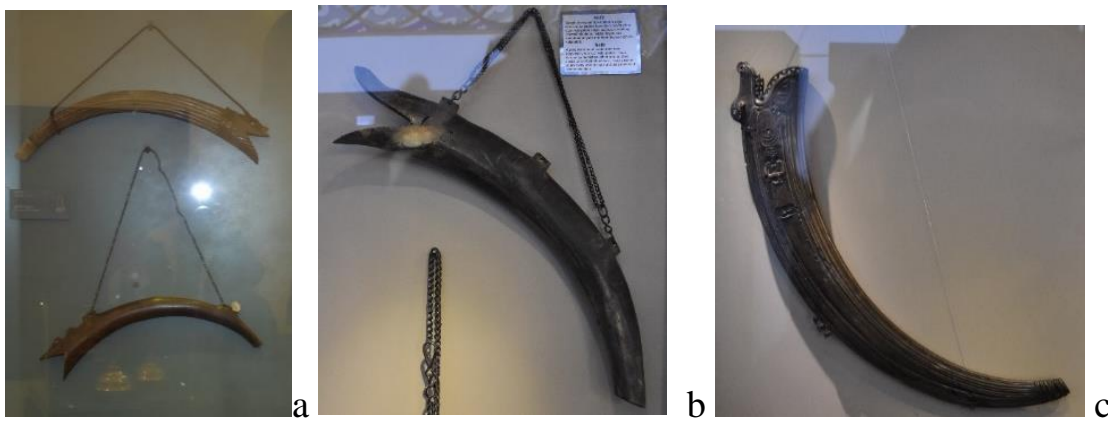

Fotoğraf 30a-b-c. Ejder Figürlü Nefirler a.Konya Mevlana Müzesi (Saklavcı 2017). b-c Hacı Bektaş Müzesi (Saklavcı, 2018).

Hacı Bektaş Veli Türbesi'nde bulunan Kırkbudak Şamdanın bitkisel kollarının uçlarındaki mumlukların alt kısımlarında ejder başları tasvir edilmiştir (Foto. 31). 


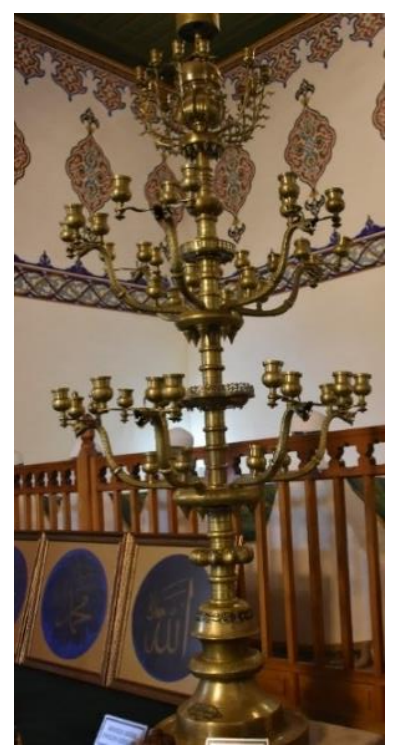

Fotoğraf 31. Hacı Bektaş Türbesi, Balım Sultan Müzesi, Ejder Figürlü Kırkbudak Şamdan (Saklavc1, 2018).

Müzelerde yer alan bu dönem eserleri ejder figürlerinin sembolik anlamlarını yitirmeden kullanıldığını göstermektedir. Kayseri’nin Develi ilçesinde aynı mahalle içerisinde yer alan ve birisi 1912 inşa tarihi üç evin giriş cephelerinde ejder başlı çörtenler bulunmaktadır. Selçuklu stilinde işlenen ve Karamanoğulları dönemine ait Araboğlu Camii çörtenini (Foto. 32a) andıran figürlerin gözleri badem şeklinde, ağızları açık, ağızlarının üst kısmı yukarı doğru kıvrık ve boyunlarında zincir görülmektedir (Foto. 32b). Bu çörtenler su ve bolluk sembolü olan ejderha figürünün işlevsel olarak günümüze kadar kullanıldığını göstermektedir.

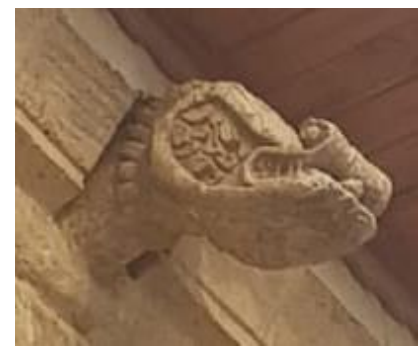

Fotoğraf 32a. Karaman Araboğlu Cami Çörteni (Saklavc1, 2017). 

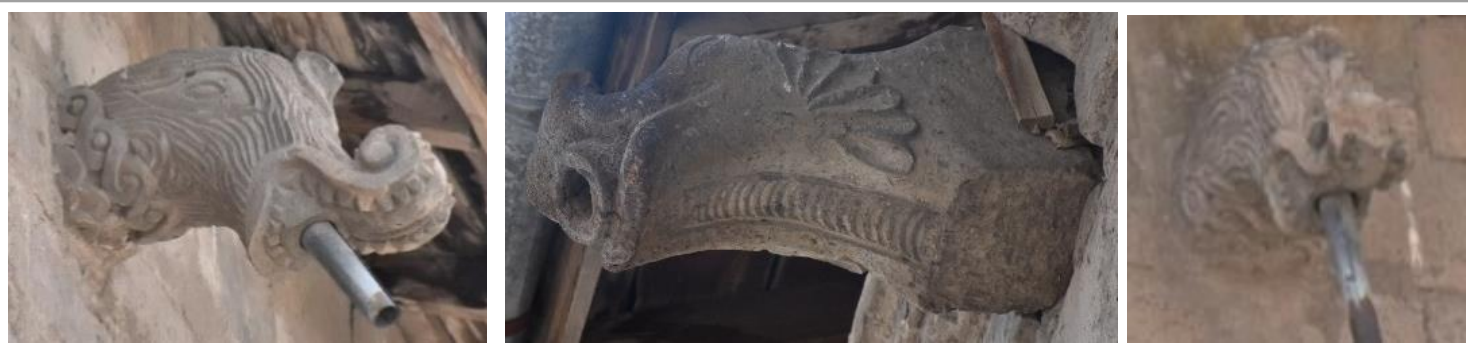

Fotoğraf 32b. Develi İlçesi Ejder Figürlü Çörtenler (Saklavc1, 2017).

$\mathrm{Bu}$ bilgiler ve konumuz ile ilgili kaynaklar ışığında çalışmamızda yer alan yapılardaki figürler değerlendirildiğinde Diyarbakır Kalesi Ulu Beden Burcu ve Hasankeyf Kalesi Küçük Saray'daki karşılıklı 2 kanatlı arslan figürünün hükümdarlık ve hâkimiyet sembolü oldukları düşünülmektedir (Parla, 2016: 12). Grifonlar başlarında taçları ve ejder başıyla biten kuyrukları ile kanatlı arslan gibi koruyucu, tılsım olarak kullanılmıştır (Öney, 1969c: 37-40; Öney, 1992: 52). Hayvan mücadele tasvirleri İslâmiyet'ten sonraki Türk sanatında politik gücün sembolü olarak kullanıldığ1 gibi bazen de astrolojik anlamlar taşımaktadır (Çoruhlu, 1993: 130). Kaleler düşmana karşı savunma mekânı olduğu için tahtı ve hâkimiyeti temsil eden figürlerin kuyruklarındaki ejderler de karşı gücü, düşmanı simgelemektedir. Bu sahneler zit prensipler olan iyilik- kötülük, güneş-ay, aydınlık-karanlık, düşman-yerli mücadelesi olarak değerlendirilebilir (Öney, 1969b: 187-188; Öney, 1992: 41).

Hüdavend Hatun Kümbeti'nin güneybatı cephesinde yer alan, kuyruğu ejder başı ile biten karşılıklı iki arslan figürünün arasındaki dışa taşkın iki rozet kozmik tasarım olduklarını düşündürmektedir. Çaycı, arslan-ejder ilişkilerinde gezegenler kuşağı içerisinde arslanın güneşi, ejderin ise ayı sembolize ettiklerini belirtmektedir (Çayc1, 2002: 104).

Erçiş Zortul Kümbeti'ndeki figürlerin türbede yatan kişiyi korumak üzere tılsım olarak yerleştirildiğini söylemek mümkündür (Öney, 1992: 52). Bazı kaynaklarda bu figürler ve batı taraftaki Selçuklu arması olan çift başlı kartal kabartmasının, kümbette yatan Karakoyunlu Hükümdarı Kara Yusuf'u temsil ettiği geçmektedir (Öney, 1969c: 1-64; Çoruhlu, 2014: 62).

Hüdavend Hatun Kümbeti ve Döner Kümbet'te tasarlanan siren figürlerinin de yapıyı korumak için kullanılmış olduğunu düşünebiliriz. Evrenin merkezini belirlediği, yolcuları koruduğu ve uğur getirdiği varsayılan sirenler, Orta Asya Türk mitolojisinde ölen kişiye gökyüzü seyahatini yaptıran koruyucu yaratıklar olarak yer almaktadır (Öney, 1992: 52).

Dazya (Gümüş Top) Köyü arslan figürlerinin kuyruklarıdaki ejder figürleri ile mücadelede aydınlığın karanlığa, iyinin kötülüğe üstünlüğü sembolize edilmiş olduğu söylenebilir. Zaviyeler her yaştan ve her zümreden kişilerin dinî ilimleri öğrendiği, aynı zamanda yolcuların konakladığı mekân olması sebebiyle eğitim görenleri aydınlığa ulaştıran bir mekândır. Talebeleri temsil eden arslanların cahillik ve nefisleri temsil eden ejderle mücadelesini sembolize ettiği düşünülebilir. Figürlerin yapıyı, banisini ve içerisindekileri koruması için tılsım olarak yerleşteştirilmiş olması da muhtemeldir.

Kesikköprü Han'da yer alan kompozisyonda arslanın kuyruğundaki ejder ve kuş figürlerinin zit kuvvetlerin savaşını temsil ettiğini söylemek mümkündür. İyilik ve zaferin temsilcisi arslan figürü kötülük ve zayıfı temsil eden ejdere karşı kuvveti ve galibiyeti sembolize etmektedir (Öney, 1992: 37; Öney, 1969c: 40).

Divriği Ulu Cami batı taçkapısı çift başlı kartal figürlerinin yapının banisi Ahmet Şah'ı, kuzey duvardaki tek kuş ise eşi Turan Melek'i de sembolize ettiği düşünülmektedir. Bazı kaynaklarda da çift başlı kartalın Anadolu Selçuklu Sultanı Alâeddin Keykubad'ın egemenliğini sembolize ettiği belirtilmektedir (Akç1l, 2004: 142-143). Gierlich de Beyşehir Gölü'ndeki 
Kubadabad'daki yapılan kazılar sırasında bulunan ve "es-sultan" yazısı ile birlikte çift başlı kartal tasvir edilen çiniden yola çıkarak yapıdaki çift başlı kartalın Selçuklu Sultanı Alâeddin Keykubad'ın hanedan amblemi olduğunu belirtmektedir (Gierlichs, 1996: 115).

Öney, Hüdavend Hatun Türbesi'ndeki çift başlı kartal ve ejder figürlerini Orta Asya Şaman inançları ile ilişkilendirmiş, mezar ile ilişkili bir kabartma olarak değerlendirmiştir. Figürlerin çevresindeki bitkisel bezemelerin şamana gökyüzü ya da yer altı seyahatlerinde merdiven vazifesi yapan hayat ağacı olabileceğini belirtmektedir. Bu kompozisyonda çift başlı kartalın bu yolculuğa yardımc1 olduğunu, ejder figürlerinin de Şamanı kötü ruhlardan koruyucu unsurlar olduğunu düşünmektedir (Öney, 1967: 153-154). Türbedeki çift başlı kartal figürünün gücü, hâkimiyeti, aydınlık ve güneşi güçlü olan tarafı temsil ederken kuyrukta yer alan ejder figürleri zıt prensipler olan yer altı karanlık ve ayı sembolize ettiğini söylemek de mümkündür. Bu zıt prensipler iyilikkötülük, güneş-ay, aydınlık-karanlık, düşman-yerli mücadelesi olarak düşünülebilir (Öney, 1969b: 187-188). Erçiş Zortul Kümbeti'nin diğer cephelerinde yer alan tavus kuşu ve çift başlı kartal figürlerini yapıların işlev benzerliklerinden dolayı aynı şekilde hayat ağacı tasarımı olarak değerlendirmek mümkündür. Yapılarda tasarlanan kartallar aynı zamanda adaletin de sembolüdür ve Orta Asya inançlarında totem olarak da kullanılmaktadır (Çoruhlu, 2011a: 174).

Tuzhisar Sultan Han'ın avlusunda dönemde nadir olarak inşa edilen ve sultanın kudret ve hâkimiyetini temsil eden (Gündüz, 2002: 299) köşk mescidin kemerleri üzerindeki ejderler de kozmolojik olarak yapıyı, dolayısıyla sultanı koruyan bekçilerdir diyebiliriz. Mescidin güney ve doğu kemer alınlığındaki ejder figürleri yapıyı iki taraftan koruma altına almıştır. Yazar, üzerinde ejder figürlerinin yer aldığı kemerlerin bir kozmik bir tasarım olabileceğini düşünmektedir (Yazar, 2004: 353). Mescid İslâmî metinlerde, el-Beytu'l Ma'mûr olabileceği düşünülen, göksel bir makamı sembolize etmektedir. Bu bilgilere göre kutsallığ Kâbe'nin yeryüzündeki kutsallığ gibi olan elBeytu'l Ma'mûr, semada Kâbe'nin hizasında yer alan bir evdir. Burada her gün yetmiş bin melek namaz kılmaktadır (Kılıç, 1994: 64). Kâbe'nin dünyanın merkezindeki konumu ve köşk mescitlerin konumu özdeşleştirilerek kozmik bir eksen olabileceğini düşündürmektedir. Ayrıca birer göksel unsuru olan kemerdeki ejder figürleri ile köşk mescidin konumu arasında kozmik bir ilişki olduğu izlenimi vermektedir. Ejderlerin senelik dönüşü ayarlaması Kâbe etrafında yapılan tavafı akla getirmektedir. Bu fikirden hareketle mücadele halindeki ejder figürlerinin iyilik ve kötülüğe teşvik eden zıt nefsani duyguları temsil ettiği düşünülebilir.

\section{Sonuç}

Ejder figürü, Orta Asya'dan Anadolu'ya kadar geniş bir coğrafyada ortaya çıkan uygarlıkların sanatlarında kullanılmış ve olumlu-olumsuz birçok farklı inancın sembolü olmuştur. Ejder figürleri İslam sanatında Türklerin Anadolu'ya gelmesinden sonra yaygınlaşmış, Anadolu Selçuklu dönemi eserlerinde taş, çini, maden, minyatür sanatlarında yoğun olarak kullanılmıştır. Ortaçağ Anadolu Selçuklu mimarisinde H. 605 /M.1208 tarihi ve H.777 / M. 1375 tarihi arasındaki dönemde bazı cami, kale, türbe, kervansaray ve türbede ejder figürü arslan figürlerin kuyruklarında, bazılarında çift başlı kartal ve siren figürlerinin kanatlarında tasarlanmıştır.

Çalışma yaptığımız dönem içerisindeki yapılarda tespit edilen ejder figürlerinin Selçuklu stilinde badem gözlü, sivri kulaklı, sivri dişli, dili dışarıda tasvir edildiği görülmektedir. Ejder figürleri yapılarda evren, gökyüzü, canlılık, karanlık ve kötülükle mücadele, yer altı, gezegen simgesidir. 12 Hayvanlı Türk Takvimi’nde ejder yılını temsil etmektedir. Ejder figürlerinin yapılarda kullanımlarını değerlendirdiğimizde kale, han ve camide genellikle arslan ve çift başlı kartla figürlerinin sultanı, devleti temsil eden güç göstergesi, kuyruklarında saldırmaya hazır olarak tasvir edilen ejder figürlerin ise düşmanı sembolize ettiğini söylemek mümkündür. Arslan figürleri yapılarda güç ve galibiyet sembolü olurken kanatlı aslan figürlerinin olağanüstü kuvveti ifade ettiği aynı figür üzerinde iki zıt prensibi birleştirmek üzere bir arada uygulandığını düşündürmektedir. Tek 
ve çift başlı kartal figürleri yapılarda sultanı temsil ederken kanatları ejder figürü ile biten çift başlı kartal figürlerinin de çok daha güçlü olacak şekilde bir arada verildiği söylenebilir. Türbelerde yer alan kompozisyonlar değerlendirildiğinde hayat ağacı unsurları olan arslan, çift başlı kartal ve ejder figürlerinin uygulanışları farklı olsa da yapıda yatan kişiyi koruyan tılsım ve muska olarak kullanıldıklarını söylemek mümkündür.

Ejder figürlerinin kökleri milattan önce Orta Asya'ya dayanmakta, oradan Anadolu'ya geçerek yoğun bir şekilde uygulanma alanı bulmaktadır. Günümüze kadar gelen süreç içerisinde figürlerin, kurganlardan çıkarılan ahşap ve metal buluntularda, kitap resimlerinde, minyatürlerde, müzelerde sergilenen taş ve madeni eserlerde, Andolu Türk mimarisi örneklerinde, 19. yüzyıl tarikat eşyalarında ve son dönem yapılarında hemen hemen aynı sembolik anlamları taşıdığı görülmektedir. Çalışmamız gerek tek başına ve ikili ejder tasarımlarında gerekse konumuzu teşkil eden kanat ve kuyruk uygulamalarında ejder figürlerinin çoğunlukla olumsuz yönlerinin ön plana çıktı̆̆ını bazı kompozisyonlarda ise figürün gücüne güç katma ve çift güç olarak vurgulandığını göstermektedir. Ayrıca milattan önce Orta Asya'da kullanılmaya başlanan figürler, Türkler Orta Asya'dan, Anadolu'ya gelerek, yeni inanç ve kültürlerle tanışmış olsalar da tarihi süreç içerisinde anlamlarını yitirmemiş, kadim inançların izlerini taşıyarak işlevsel olarak kullanılmaya devam etmiş̧tir. Doğaüstü gücü temsil eden ejder kuyruklu arslanlar ve kanatları ejder figürü ile biten çift başlı kartal ve siren figürleri de aynı figürde birlikte kullanılarak karşıt güçleri birleştirmek üzere birlikte tasarlandığı düşündürmektedir. Böylelikle figürler çok daha kuvvetli olacak şekilde bir arada verilmiştir. Ejder figürleri farklı devir ve kültürlerde, farklı sanat eserlerinde uygulansalar da ait oldukları toplulukların kültür düzeylerini ve sosyal yaşamlarını 1şık tutmaktadır. Böylece insanların duygu ve düşüncelerine yansıtmada bir araç olan figürler içerdikleri anlamlar ve aktardıkları tarihî unsurların insan hayatında işlevsel ve etkileyici bir rol üstlendiklenmektedir.

\section{Kaynakça}

Acun, H. (1993). Tokat-Pazar Mahperi Hatun Kervansarayı Çeşmesinin ejder başlı lülesinin bulunuşu. Yllmaz Önge'ye Armağan, 263-266.

Akalın, Ş. (1998). Hudâvend Hatun Kümbeti. TDVİA. Türkiye Diyanet Vakfi Yay., 28, 284-285.

Akçıl, N.Ç. (2004). Mengücüklüler (Mimari). TDVİA. Türkiye Diyanet Vakfı Yay., 29, 142-143.

Akok, M. (1969). Kayseri'de Tuzhisarı, Sultanhanı, Köşk Medrese ve Alaca Mescit diye tanınan üç Selçuklu mimarî eserin rölövesi. Türk Arkeoloji Dergisi, 17(25) 41.

Altıer, S. (2008). Bektaşi İkonografisi Üzerine Bir Deneme: Hacı Bektaş Veli Müzesi’ndeki Figürlü Keşkül-ü Fukaralar. SDÜFEFSBD, 17, 101-116.

Altun, A. (1978). Anadolu'da Artuklu Devri Türk mimarisinin gelişmesi. Kültür Bakanlığı Yay.

And, M. (2015). Minyatürlerle Osmanl- İslâm mitologyası. Yapı Kredi Yay.

Arel, H. (1962). Divriği Ulu Cami kuzey portalinin mimarî kuruluşu. Vakfflar Dergisi, 113-127. https://hdl.handle.net/11352/1395

Arık, O.R. (2007). Anadolu toprağının hazinesi çini. Kale Grubu Kültür Yay.

Aslanapa, O. (1971). Diyarbakır Sarayı kazasından ilk rapor. Türk Arkeoloji Dergisi, 11, 10-18.

Aslanapa, O. (2007). Anadolu'da ilk Türk mimarisi başlangıç ve gelişmesi. Ankara: AYK.

Bağcı, S. (1998). Gerçeğin suretinin saklandığı yer: ayna. Sultanların aynaları. TC Kültür Bakanlığı Yayınları. 
Bakırer, Ö. (2000). Onüçüncü ve ondördüncü yüzyıllarda Anadolu mihrabları. TTKB.

Bingöl, E. (2020). Erciş Karakoyunlu Dönemi tarihi ve kültür varlıkları, [Yüksek Lisans Tezi]. Ağrı İbrahim Çeçen Üniversitesi Sosyal Bilimler Enstitüsü Tarih Ana Bilim Dal1.

Bozer, R. \& Çeken, M. (2016). Anadolu Selçuklu Mimarisi Müze Eserleri. Türkiye Cumhuriyeti Cumhurbaşkanlığı.

Cantay, G. (2014). Anadolu Selçuklu ve Osmanlı darüşşifaları. AKMY.

Çaycı, A. (2002). Anadolu Selçuklu Sanatı'nda gezegen ve burç tasvirleri. T.C. Kültür Bakanlığı Yay.

Çetin, Y. (2013). Mardin Savurkapı (Sitti Radviye) Hamamı'nda bulunan figürlü taş plastik süslemelerin Türk Süsleme Sanatı ikonografisi açısından bir değerlendirmesi”. Uluslararası Sosyal Araştırmalar Dergisi The Journal of International Social Research, 6(25), 178-188.

Çevrimli, N. (2012). Değişik işlevli bir grup madeni eser örnekleri üzerinde görülen ejder figürleri hakkında bir değerlendirme. Vakıflar Dergisi, 37, 193-222.

Çobanoğlu, A.V. (2012). Divriği Ulucami. TDVİA. Türkiye Diyanet Vakfi Yay., 42, 95-99.

Çoruhlu Y. (1993). İslamiyetten önceki Türk sanatında hayvan mücadele sahneleri. Sanat Tarihinde İkonografik Araştırmalar, Güner İnal'a Armağan, 117- 141.

Çoruhlu, Y. (2011a). Türk mitolojisinin ana hatları. Kabalcı Yay.

Çoruhlu, Y. (2011b). Erken Devir Türk Sanatı. Kabalcı Yay.

Çoruhlu, Y. (2014). Türk sanatında hayvan sembolizmi. Kömen Yay.

Çulpan, C. (1975). Türk taş köprüleri (Ortaçağdan Osmanlı devri sonuna kadar). TTKB.

Denknalbant, A. (2009). Sultan Hanı. TDVIA. İstanbul: Türkiye Diyanet Vakfı Yay., 37, 504-505.

Diez, E. \& Aslanapa, O. (1955). Türk Sanatı. İTÜ Yay.

Durukan, A. (2012). Ortaçağ'ın sönmeyen yıldızı: Divriği Ulu Cami ve Darüşşifası. Hayat Ağacı Sivas Şehir Kültür Dergisi Özel Saylst. (Ed. Ahper Nuri Delican), 19, 19-40.

Esin, E. (1969-1970). Selçuklu sanatı evren tasvirinin Türk ikonografisinde menşeleri. Selçuklu Sanatı Araştırmaları I, 161-182.

Gabriel, A. (1934). Monuments Turcs D’Anattolie II Amasya Tokat Sivas, E. De. Boccard.

Gabriel, A. (1993). Diyarbakır Surları. Çev. Kaya Özsezgin, Diyarbakır Tanıtma, Kültür ve Yardımlaşma Vakfi.

Gabriel, A.L. (1999). Anadolu'da Türk anıtları I Niğde, (Haz. Faruk Yılmaz). Niğde Belediyesi Yay.

Gierlichs, J. (1996). Mittelalterliche tierreliefs in Anatolien und Nordmesopotamien. E. Wasmuth.

Görür, M. (1999). Beylikler dönemi mimarisinde taş süsleme. [Yayımlanmış doktora tezi]. Hacettepe Üniversitesi Sosyal Bilimler Enstitüsü Sanat Tarihi Anabilim Dalı.

Gündoğdu, H. (2004). Tokat'tan birkaç figürlü kabartma hakkında. Güzel Sanatlar Enstitüsü Dergisi, $13,65-93$.

Gündüz, S. (2002). Karatay Han portalleri süsleme programı ikonografisi. Ortaçağ'da Anadolu Prof. Dr. Aynur Durukan'a Armağan, 291-307. 
İnal, G. (1971). Susuz Handaki ejderli kabartmanın Asya kültür çevresi içindeki yeri. Sanat Tarihi Yıllığı, 4, 153-181. https://dergipark.org.tr/tr/pub/iusty/issue/34600/382102

Karaduman, H. (2005). David Koleksiyonu'nda bulunan bazı Türk Eserleri ve düşündürdükleri. Vakuflar Dergisi, 29, 481-496.

Keskiner, C. (2007). Turkish Motifs, Turkish Touring and Automobile Association.

Kılıç, S. (1994). Kâbe'deki sembolizm üzerine bir deneme. İslâm'da Sembolik Dil, İnsan Yay., 4973.

Kuban, D. (2010). Divriği mucizesi. Yap1 Kredi Yay.

Nicolle D. (2013). The Zangid Bridge of Ğazīrat ibn 'Umar (Ayn Dīwār/Cizre): a new look at the carved panel of an armoured horseman, d'etudes orientales. Bulletin, 223-264.

Ocak, A.Y. (2013). Alevî-Bektaşî inançlarının İslâm öncesi temelleri. İletişim Yayınları.

Öney, G. (1967). Niğde Hüdavend Hatun Türbesi figürlü kabartmaları. Belleten, 31(122), 143-167.

Öney, Gönül (1969a). Anadolu Selçuklu sanatında ejder figürleri. Belleten, 33(130), 171-192.

Öney, G. (1969b). Anadolu Selçuklu mimarisinde arslan figürü. Anadolu (Anatolia), 13, 1-41.

Öney, G. (1971). Selçuklu mimarisinde aslan figürü, Lion Figures in Anatolian Seljuk Architecture. Anadolu,(Anatolia), 13, 1-64.

Öney, G. (1992). Anadolu Selçuklu mimari süslemesi ve el sanatları. Türkiye İş Bankası Kültür Yay.

Önkal, H. (2015). Anadolu Selçuklu türbeleri. AKMY.

Özbek, Y. (2007). Tuzhisar Sultan Hanı. Anadolu Selçuklu Kervansarayları Selçuklu Dönemi Kervansarayları. (Ed. Hakkı Acun). Ankara: Kültür ve Turizm Bakanlığı Yay., 175-193.

Özkan, E. (1993). Cizre Köprüsü. TDVİA. Türkiye Diyanet Vakfi Yay., 8, 40.

Özkarc1, M. (2001). Niğde'de Türk mimarisi, Ankara: Türk Tarih Kurumu Yay. https://doi.org/10.33404/anasay.534493

Özkarcı, M. (2007). Niğde (Mimarî). TDVİA. Türkiye Diyanet Vakfı Yay. 33: TTKB. 95-98.

Özkeçeci, İ. \& Özkeçeci Ş.B. (2007). Türk sanatında tezhip. Seçil Ofset.

Özüdoğru, Ş. (1989). Karaman'da Türk mimari eserleri süslemeleri, Mimar Sinan Üniversitesi Sosyal Bilimler Enstitüsü, Sanat Tarihi Ana Bilim Dalı, Doktora Tezi.

Parla, C. (2016). Diyarbakır Surlarının Artuklu dönemi figürlü kabartmaları. Akademik Sosyal Araştırmalar Dergisi, 4(33), 1-23. 10.7827/TurkishStudies.8365

Rudenko, S.İ (1968). Drevneyşie v Mire Xudojestvennie Kovrie Tkani.

Saklavcı, F. (2015). Alevî-Bektaşî inançlarında sembol ve motifler. Cumhuriyet Üniversitesi Sosyal Bilimler Enstitüsü, Yüksek Lisans Tezi.

Sözen, M. (1972). Anadolu medreseleri. 2, İTÜ Matbaas1.

Şahin, İ. (2002). Kırşehir. TDVİA. Türkiye Diyanet Vakfı Yay., 25, 481-485.

Tanındı, Z. (2006). Siyer-i Nebî İslam tasvir sanatında Hz. Muhammed'in hayatı. Hürriyet Vakfı Yay.

Top M. (1999). Erçiş Zortul Kümbeti. Dünyada Van Valiliği Kültür ve Sanat Dergisi, 7(19): 23-26.

Ülgen, A.S. (1962). Divriği Ulu Camîi ve Darüş-ş̂fası. Vakıflar Dergisi, 5, 93-98 
Yazar, T. (2004). Türk mimarisinde 'kozmik eksen' tasarımları. Çağdaş Türklük Araştırmaları Sетровуити 8-10 Mayls 2002, 348-361.

Yurdakul, E. (1969). Tokat Vilâyetinin Gümüsstop (Dazya) Köyündeki XIV 'ncü yüzyıla ait eski eserler. Vaklflar Dergisi, 8, 243-247.

Yücel, A. (1997). Hacı Bektaş Velâyetnâmesinde ejderha motifi. Hacı Bektaş Veli Armağanı. Gazi Üniversitesi Türk Kültürü ve Hacı Bektaş Veli Araştırma Merkezi, 115-120.

https://www.haberler.com/ani-de-kazi-calismalarinda-bulundu-muzede-9911639haberi/29.07.2021.

http://journals.openedition.org/beo/1404 29.07.2021. 